\author{
PAWEE T. DOBROWOLSKI \\ Collegium Civitas, Warsaw
}

\title{
POPULAR JUSTICE OR WHY WERE THERE NO SANS-CULOTTES IN AMERICA?
}

\begin{abstract}
The article applies a comparative perspective to assess the onset of the two 'successful' eighteen-century revolutions - the American and the French. The Boston events of March 1770 are compared with those of Paris in July 1789: in both cases 'the people' faced the soldiers, riots and politically generated violence led to bloodshed, but the subsequent actions of the insurgents showed a marked difference in understanding the sense of justice and the ways of promoting revolutionary discourse. Boston patriots relied on the English-based system of common law, were ready to condemn their own radicals and did not wish plebeian justice to prevail. They hoped for a perestroika, not for a revolution. The French - finding no culprits to condemn, and having as of yet no legal institutions of their own to use - were willing to disregard the legal continuity of the state and to search for more radical solutions. Key w ords: Revolution, Boston, Paris, massacre, Bastille, violence.
\end{abstract}

Bullets fired in a city street into a crowd of demonstrating civilians seem to be, regardless of the historical period, reason enough to confirm the existence of a social crisis. They may even signal that riots are about to break out or they may be a harbinger of a revolution. This applies to the events of 1970 in Gdańsk or of 2011 in Cairo or Tripoli, as well as to much earlier cases of bloodshed caused by the army on the streets of cities as well as consequences of such tragedies.

On the evening of 5 March 1770 in Boston's King Street, a unit of the 29th Regiment, part of the city garrison, responded with fire to a mob's aggression and killed five citizens. As William Sewell Jr. argued, we need to rehabilitate such individual historical events, individual elements of the chain of événements and place them in social contexts which determine culturally significant 'little dramas'. These, in turn, help us to understand broader, structural transformations. Inspired, as he himself admitted, by 
works of Marshall Sahlins, Irving Goffman and Anthony Giddens, Sewell constructed his argument as a sociologist and as an historian, bearing in mind primarily the 'chain of events' and 'structural transformations' depending on it, that took place in July 1789 in Paris. We have become used to see in them a 'revolution', but were they perhaps just more or less successful perestroikas? ${ }^{1}$

The merits of comparative history, a tool historians will always find difficult to handle, encourage us to attempt a parallel and multifaceted 'interpretation of the situation' usually regarded as the 'beginning' of the two eighteen-century revolutions most fraught with consequences: the American and the French. Both have acquired a considerable body of literature, as for historians on both sides of the Atlantic the American March 1770 and the Parisian July 1789 have invariably been an area of intellectual fascination and a series of 'small and great stories' that launched processes leading to fundamental changes in the image of the world of the eighteen and subsequent centuries. As Mlada Bukovansky writes, using America and France as examples to present the process of change that replaced the dynastic and monarchic legitimacy of power with its new, 'popular' form, its most evident characteristic was the growing aggression of the stakeholders in this transformation. ${ }^{2}$ Comparing the American revolt against 'British imperialism' with the French rebellion against social (and fiscal) bankruptcy obviously has numerous limitations. However, such a perspective of seeing collective reactions can be proposed because the catalogue of threats was similar to both societies: in brief, the awareness of economic (and subsequently political) domination by foreigners (America), and economic collapse as well as the need to change the formula according to which the state functioned (France).

${ }^{1}$ William H. Sewell Jr., 'Historical Events as Transformations of Structures: Inventing Revolution at the Bastille', Theory and Society, 25, 1996, pp. 841-81. Cf. Giovanni Levi, 'On Microhistory', in New Perspectives on Historical Writing, ed. Peter Burke, Cambridge, MA, 1991, pp. 93-113. This way of exploring the history of the revolution has acquired many followers - an attempt that can be regarded as successful is Timothy Tackett's When the King Took Flight, Cambridge, MA, 2003, while less successful is Michael P. Fitzsimmons's The Night the Old Regime Ended: August 4,1789 and the French Revolution, University Park, PA, 2003. Cf. Raymond Birn, 'Reinventing le Peuple in 1789', History Teacher, 23, 1990, 4, pp. 363-73, Sarah Maza, 'Politics, Culture and the Origins of the French Revolution', JMH, 61, 1989, 4, pp. 704-23.

${ }^{2}$ Mlada Bukovansky, Legitimacy and Power Politics: The American and French Revolutions in International Political Culture, Princeton, NJ, 2002; Peter Howell, 'Burke, Paine, and the Newspapers: An Archaeology of Political Knowledge 1789-93', Studies in Romanticism, 43, 2004, 3, pp.357-98. Rett R. Ludwikowski, 'The French Declaration of the Rights of Man and Citizen and the American Constitutional Development', American Journal of Comparative Law, 38, 1990, pp. 445-62. 
To initiate a revolution or, rather, to turn a social protest into a structural transformation of the state requires - at the stage of street dissent bloodshed, identification of one's own martyrs and foreign perpetrators as well as efficient propaganda. A revolution, as Peter Howell reminds us, is an offer of a violent break of the linear continuity of time and the replacement of the 'old' with an attractive 'new'. What is needed is social legitimacy, that is, the creation of a political system in which a vast majority of its stakeholders - or, as we would say today, citizens - are willing to support it as the most advantageous alternative. ${ }^{3}$ Before we move on to the consequences of the events on the streets of Boston, which put this model into effect, we should recall the well-known 'Parisian drama', usually linked to the events of 14 July - the storming and capture of the Bastille.

The chronological placement of the 'beginning of the revolution' is a fascinating venture, though not very convincing in a broader perspective. The results of an historical investigation of this sort are often questionable, because both contemporary witnesses and historians studying their accounts lack a sufficiently balanced cognitive instrument enabling them to pass an authoritative and impartial judgement. Yet the attempts themselves are very interesting indeed. As Lawrence M. Bryant has shown, between the deputies to the Estates General summoned to Versailles and the royal court a symbolic war had been waged from the very beginning - May 1789. This was a war in which the Third Estate gradually took over the semiotic order of power manifestation, a game involving the use of the 'monarchic' space by a determined 'body politic' well aware of its goals. A theatrical performance was being played out in public, a performance of gestures clear to those present - of standing up and sitting down, of studied silence, applause (the applause of the crowds became a political novelty), symbolism of the colours of garments (black colours of the Third Estate) as well as the order and gradation of appearing in collective processions and celebrations. ${ }^{4}$ It could be argued that from the point of view of the constitutional order

${ }^{3}$ Howell, 'Burke, Paine, and the Newspapers', p. 363. Evidence of the rational argumentation of political legitimacy was expounded by Ronald Rogowski, Rational Legitimacy: A Theory of Political Support, Princeton, NJ, 1974; when it comes to the decision of the French National Assembly, it was applied by Harriet B. Applewhite, 'Political Legitimacy in Revolutionary France, 1788-1791', Journal of Interdisciplinary History, 9, 1978, 2, pp. $245 \mathrm{ff}$.

${ }^{4}$ Lawrence M. Bryant, 'Royal Ceremony and the Revolutionary Strategies of the Third Estate', Eighteenth-Century Studies, 22, 1989, 3, pp. 413-50. The ideology and atrophy of the concept of 'l'éspace du roi' - the royal space of Versailles - are discussed by William R. Newton, L'Espace du roi: La Cour de France au chateau de Versailles, 16821789, Paris, 2000. Cf. also Howell, 'Burke, Paine, and the Newspapers', pp. $363 \mathrm{ff}$. 
of the monarchy the decision of the 'Third Estate', convened in Versailles, of 17 June 1789 that a National Assembly be constituted was yet another 'revolution' - after the symbolic revolutions - as it posed a fundamental challenge to the absolute royal power and questioned a centuries-long political construct. The court understood these challenges well from the very beginning. A measure of its defeat in the summer of 1789 can be found in a comparison of the language of the royal decree of 23 June forbidding the 'estates' to sit together, and defending the principle of particularism and exclusive sovereignty of the monarchy with the setting, speeches and gestures of the monarch during his political capitulation: his visit to the revolted city of Paris on 17 July. For the observers the June usurpation, not to mention the subsequent excesses of the mob, was a revolution. The American envoy Gouverneur Morris noted the 'wild joy' of the people breaking free from the custody of the state, while Pierre-Augustin Beaumarchais, who feared the hostility of the people in the streets, decided to move to the countryside to wait there for the end of the turbulence. For others the disaster came only with the capture of the Bastille. The Russian Ambassador Ivan Simolin, who, impressed by the events associated with its storming, compared the July Paris to a 'tigers' den' and sent a dispatch saying that 'la revolution en France est consommée et l'autorité royale anéantie'. ${ }^{5}$ The barrage of historical accounts concerning the significance of the July events was summed up two centuries later by François Furet and Ran Halévi, who wrote that the summer of 1789 had given France its distinctive and modern political legacy. ${ }^{6}$ The reference to Furet and the intel-

${ }^{5}$ Simolin's activities included espionage (he managed to obtain the codes of the French Ministry of Foreign Affairs). He left Paris on 17 February 1792 and his property and possessions were confiscated. Quoted after Pierre Caron, 'La tentative de contre-révolution de juin-juillet 1789', Revue d'histoire moderne et contemporaine, 8, 1906-07, 1 and 9, pp.3-34, 649-78 (p. 675); Jacques Marseille and Dominique Margairaz, 1789 au jour le jour, Paris, 1988, p. 250. Anatole G. Mazour, 'The Russian Ambassador in Paris, 1789-1792', Russian Review, 1, 1942, 2, pp. 86-93 (quotation on p. 87), discusses the ambassador's correspondence after Literaturnoe Nasledstvo, vol. 29-30, Moscow 1938, pp. 343-538. Marie-Jose Fassiotto, 'Gouverneur Morris, peintre oublie de la Révolution française', French Review, 62, 1989, 6, p. 1002. Beaumarchais's letter of 23 July is published by René Pomeau, 'Beaumarchais et les lendemains du 14 juillet 1789. Une lettre inédite', Revue d'histoire littéraire de la France, 97, 1997, 6, pp. 1024-30. For more on the emergence of the 'body politic' and the ideology of the revolution among the 1315 deputies to the Assembly, see Timothy Tackett, Becoming a Revolutionary: The Deputies of the French National Assembly and the Emergence of a Revolutionary Culture, 1789-1790, Princeton, NJ, 1996.

${ }^{6}$ François Furet and Ran Halévi, 'L'année 1789', Annales. Économies, Sociétés, Civilisations, 44, 1989, 1, p. 4. 
lectual 'revolution' he brought about in the entire historiographical tradition, which for over two centuries has been passing judgements on the revolution, requires an additional remark. Very briefly, given the wealth of analyses, we need to remember that this new perspective of debates about the French Revolution was inextricably linked to the contemporary, twentieth-century discourse about the quality and transformations of the French and European political culture. A similar link can be found in the opinions on the 'Boston massacre' of March 1770, concerning not only the event itself, but rather the complex relations between the 'legitimate (that is, the British) authorities' and a political culture, perhaps already 'proto-democratic', certainly civic, challenging them, a political culture that gave rise to the American 'revolutionary process'.?

In the context of France it is difficult to shed the historical burden of the 'myth of the revolution', which emerged with the capture of the royal fortress in Paris. Hans-Jürgen Lüsebrink and Rolf Reichardt's analysis has allowed us to get rid of at least one illusion: the storming of the royal prison by the crowd did not turn the prisoners freed from the fetters of despotism into heroes of the following days. After all, there were only seven of them, which clearly testified to the fact that the events associated with the 'outbreak' of the revolution - both in Boston and in Paris would have few protagonists known by name. From the abyss of the 'devilish Bastille' - the title of a pamphlet published after its capture (in 1790) - emerged seven poor wretches. Four had been serving (since only 1786) life sentences for financial fraud, and the remaining three did not quite fit the image of 'prisoners of conscience' either. Auguste Tavernier, who had been in prison since 1757, was accused of being involved in a plot against Louis XV (but already on 20 July was locked up again in the lunatic asylum in Charenton, which questioned his role as an alleged conspirator), White de Malleville was incarcerated in the Bastille in 1781 on his family's request (on the grounds of dementia), while Count de Solanges

${ }^{7}$ It is virtually impossible to even summarize the debate with regard to France. In formulating the above assertion, I drew extensively on Michael S. Christofferson, 'An Antitotalitarian History of the French Revolution: François Furet's "Penser la Révolution française" in the Intellectual Politics of the Late 1970s', French Historical Studies, 22, 1999, 4, pp. 557-611; Suzanne Desan, 'What's After Political Culture? Recent French Revolutionary Historiography', French Historical Studies, 23, 2000, 1, pp. 163-96; Lynn Hunt, 'The World We Have Gained: The Future of the French Revolution', AHR, $108,2003,1$, pp.1-19. The polarization of opinions on the Boston events depending on the current experiences is well presented in Hillier B. Zobel, The Boston Massacre, New York, 1970, and Richard Archer, As If an Enemy's Country: The British Occupation of Boston and the Origins of Revolution, New York, 2010. 
had been sentenced to prison in 1784 for incest. ${ }^{8}$ Not only is it hard to see in them victims of royal despotism for whom the demonstrators stood up - the prisoners had access to healthcare and newspapers - but the reason the Bastille was stormed was not so much the 'ideological' wrath of the people of Paris directed against a symbol of the monarchy, but, rather, it was a consequence of the events - Sewell's thesis finds its confirmation here - that had taken place on the streets of Paris a few days earlier. In 'media' terms the ruthless jailers turned out to be 'faceless': the brutally murdered governor of the fortress, de Launay, was a pensioner, Major Miray, commander of the invalids making up the basis of the garrison, and his subordinate, Dumont, were killed while they were led to the execution, while two others (Asselin and Bequard) were hanged. They were pawns useless to the spontaneously emerging machine of revolutionary propaganda. ${ }^{9}$

The storming of the Bastille gave rise to the most important among the national lieux de mémoire and began the chronology of revolutionary festivities - the federation day was celebrated on its anniversary and it became, although not until 1880, the national holiday of all the French. Similarly, in America the anniversary of the 'massacre', like the remembrance of the fight against the Stamp Act (14 August and $18 \mathrm{March}$ ), was incorporated into the new patriotic calendar. It is difficult to distinguish any individual heroes of the attack on the Paris fortress. Even the thirty-three-year-old cook François Desnot, who cut off the head of the prison's governor with a knife, was rewarded not so much with a laurel wreath, which he expected for his 'patriotic act of justice', but a police interrogation..$^{10}$ Thus the after-

${ }^{8}$ Hans-Jürgen Lüsebrink and Rolf Reichardt, 'La "Bastille” dans l'imaginaire social de la France à la fin du XVIII siècle (1774-1799)', Revue d'histoire moderne et contemporaine, 30,1983, 2, pp. 196-234 (convicts released in 1789, p. 217). Cf. Brian E. Strayer, Lettres de Cachet and Social Control in the Ancien Regime, 1659-1789, New York, 1992. Tavernier's long prison 'career' and the effect of prison on his personality is discussed by Arlette Farge, Subversive Words. Public Opinion in Eighteenth-Century France, University Park, PA, 1995, pp. 178-79.

${ }^{9}$ Franz Funck-Brentano, 'La Bastille d'après ses archives', RevHist, 42, 1890, 2, p. 307.

${ }^{10}$ Funck-Brentano, 'La Bastille', pp. 287-88; Jules J. Guiffrey, 'Documents inédits sur le mouvement populaire du 14 juillet 1789 et le supplice de M. de Launay, gouverneur de la Bastille, et de Berthier de Sauvigni', RevHist, 1, 1876, 2, pp. 497-508. Cf. notes by Regina Janes, 'Beheadings', Representations, 35, 1991, p. 25. Rosemonde Sanson, Les 14 juillet, fête et conscience nationale, 1789-1795, Paris, 1976; Mona Ozouf, La Fête révolutionnaire, 1789-1799, Paris, 1976 (English edition Festivals and the French Revolution, transl. Alan Sheridan, Cambridge, MA and London, 1988); Jean-Pierre Bois, Histoire des 14 juillet, 1789-1919, Rennes, 1991; David Waldstreicher, 'Rites of Rebellion, Rites of Assent: Celebrations, Print Culture, and the Origins of American Nationalism', Journal of American History, 82, 1995, 1, pp. $50 \mathrm{ff}$. 
noon of 14 July had a collective hero - les vainqueurs or the conquerors of the Bastille. It soon turned out, however, that they lacked a visible and recognizable face, that 70 per cent of them came from the working-class suburbs and did not play any political role (perhaps with the exception of the brasseur Antoine Santerre), and that they did not become an icon of the ongoing transformations. In his funeral speech over the graves of the vainqueurs, Father Claude Fauchet pointed to the hand of providence directing the events of the day. Yet he did not dare sanction the outbreak of the popular wrath of the Paris menu peuple in the same categories. ${ }^{11}$

An attempt at a 'parallel' reading of the origins of the two revolutions enables us to compare the shots in Boston with similar events in July in Paris. Thanks to the meticulous, detective-like work carried out by Paul G. Spagnoli, we can agree today that the Paris revolution 'broke out' on the evening of 12 July and that the direct cause behind the transformation of social unrest into politically motivated riots were the events which unfolded in the centre of the city, in Place Louis XV (now Place de la Concorde) and the adjacent Tuileries Gardens. ${ }^{12}$ In both cases - Boston and Paris - the pent-up tension was released as a result of the arrival of the army. The revolution was 'caused' by the shots fired by the British infantry into the Boston crowd and the charge of the Royal Allemande regiment at the Paris demonstrators. In both cases 'foreigners' attacked 'our people': British soldiers attacked Americans (Bostonians) and 'German mercenaries' attacked the French (Parisians). The situation itself - use of the army against the demonstrators - was quite

${ }^{11}$ Of value is still Caron's 'La tentative'. Cf. Joseph Clarke, Commemorating the Dead in Revolutionary France: Revolution and Remembrance, 1789-1799, New York, 2007; Colin Lucas, 'The Crowd and Politics between Ancien Régime and Revolution in France', $J M H, 60,1988,3$, p. 428. Books regarded as the basic 'revolution textbooks' are William Doyle, Origins of the French Revolution, 3rd edn, Oxford, 1999; Roger Chartier, Cultural Origins of the French Revolution, transl. Lydia G. Cochrane, Durham, NC, 1991; Jean Egret, The French Pre-Revolution, transl. Wesley D. Camp, Chicago, IL, 1977; Jacques Godechot, The Taking of the Bastille, transl. Jean Stewart, London, 1970; George Rude, The Crowd in the French Revolution, London, 1959, pp. 53-60, Bailey Stone, The Genesis of the French Revolution: A Global-Historical Interpretation, Cambridge, 1994; François Furet, Penser la Révolution française, Paris, 1978 (Interpreting the French Revolution, transl. Elborg Forster, Cambridge,1981); Michel Vovelle, La Mentalité révolutionnaire: Société et mentalités sous la Révolution française, Paris, 1985; Robert Barrie Rose, The Making of the Sans-Culottes: Democratic Ideas and Institutions in Paris, 1789-1792, Manchester, 1983. For a useful review of research, see Jeremy Popkin, 'Not Over After All: The French Revolution's Third Century', JMH, 74, 2002, 4, pp. 801-21.

12 Paul G. Spagnoli, ‘The Revolution Begins: Lambesc's Charge, 12 July 1789', French Historical Studies, 17, 1991, 2, pp. 466-97. 
unheard of in Europe in the eighteen century. The only case that would easily come to mind of the observers - perhaps even the participants of the Boston riots concerned the events that shook London in the spring of 1768 . Problems with supplying grain to the city brought the London commoners into the streets: the riots of 28 and 30 March 1768 prompted the authorities to bring the army near the capital, the demonstration of the Wapping coal heavers of 26 April ended in three fatalities, while the St George's Field riots of 10 May led to shots being fired by soldiers, killing twelve and wounding many other people. ${ }^{13}$ In Boston and Paris the 'city' rose against the monarchy: in Paris its presence was an element of everyday life - Versailles was just a couple of hours away - in Boston its authority was more 'virtual', the monarchy (and its parliament) were far away, but it was represented by officials known by name and by the hated military garrison (brought into the city in 1768). As early as in 1766 Benjamin Franklin warned the British House of Commons that soldiers sent to America 'will not find a rebellion; they may indeed make one'. ${ }^{14}$ In both cases blood was spilled, although the term 'massacre' - invented on the spot and repeated as a description of the actions of the military was decidedly exaggerated. However, it entered common parlance and became a point of reference for the colonial discourse about oppression and persecution at the hands of the invader. ${ }^{15}$ In Boston the bullets killed five people, four of whom died on the spot, in Paris - despite the fact that there were thousands of demonstrators - the charge by Colonel de Lambesc's cavalry left no fatalities. An elderly man, 64-year-old school teacher Jean-Louis Chauvel, was hit on the head with the flat of a sword, and the tailor Jean-Baptiste Tricot sprained his leg while fleeing the cavalry. Although later doctors - examining him in November 1789 - found he suffered from stomach pain and haemoptysis, the diagnosis suggested

13 Paul Langford, A Polite and Commercial People: England, 1727-83, Oxford, 1989, pp. 374-80.

${ }^{14}$ Examination before the Committee of the Whole of the House of Commons, Thu, 13 February 1766, 〈www.franklinpapers.org/franklin/framedVolumes.jsp?vol=13\& page $=124 \mathrm{a}\rangle$ [accessed 2 October 2016], quoted also by Zobel, The Boston Massacre, p. 90 .

${ }^{15}$ In his letter of 26 March 1770 Reverend Samuel Cooper, a well-known Boston preacher, wrote to Thomas Pownall, former governor of the colony and defender of the 'American cause' that 'nothing we have ever seen has equal'd the Horrors of the Bloody Massacre on the evening of the $5^{\text {th }}$ Instant when a Party of soldiers with Capt. Preston at their head fir'd upon the Inhabitants in King Street without a civil Magistrate without the least Reason to justify so desperate a step and without any warning given to the People, who could have no apprehension of Danger', after 'Letters of Samuel Cooper to Thomas Pownall, 1768-1777', ed. Frederick Tuckerman, AHR, 8, 1903, 2, pp. 316-17. 
an effect of anxiety rather than his injuries. ${ }^{16}$ There were no martyrs in Paris, unlike in Boston, but as it turned out, their death was deliberately marginalized.

The Paris and the Boston mobs behaved similarly when confronted by soldiers, although the collective premises for the mobs' action were different. As David Garrioch has argued, the consolidation of the monarch's domination over the city - both political and military - made the Parisians 'forget how to rebel'; they lost their ability to create mechanisms of neighbourhood solidarity in favour of the police, and when faced with a crisis, primarily in July 1789 , they had to find a new way to deal with it. ${ }^{17}$ A measure of the speed with which they regained their ability of self-determination can be found, for example, in the emergence - even before the July crisis - of charitable societies, discussion clubs and political salons (although these groups did not turn for help to the people in the streets and represented the elites and not the grass roots of the new political class). ${ }^{18}$

Yet the ideological decomposition of the monarchy was proceeding so fast that despite the takeover of some state institutions there were not enough effective instruments of enforcing the basic functions of the victors: to identify, publicly condemn and sentence their opponents. The Paris police - its officers came from craftsmen's and workers' families - ceased to function in practice and refused to defend the Bastille. ${ }^{19}$ It was easier - in a way - for the Bostonians: their street protest, even offensive demonstration against the 'occupying' army, proceeded within a framework well-known to both sides of the conflict. The city 'constables', elected annually by citizens and serving as volunteer firefighters, tax collectors, municipal ushers and guards (their duties included arresting drunks), were part of the same communities with regard to which they were to fulfil (usually very reluctantly) their 'supervisory' functions. The presence of the British soldiers or uniformed policemen was treated in a completely different manner. ${ }^{20}$

\footnotetext{
${ }^{16}$ Spagnoli, 'The Revolution Begins', pp. 483-84, 491.

17 David Garrioch, Neighbourhood and Community in Paris, 1740-1790, Cambridge, 1986, p. 210.

${ }^{18}$ A brief analysis (including the amount of registration fees) was carried out long ago by Philippe Sagnac, 'Les origines de la Révolution. La décomposition de l'Ancien Régime (1788-Mai 1789)', Revue d'histoire moderne et contemporaine, 14, 1910, 2, pp. 159 ff., but cf. Jean Boutier and Philippe Boutry, 'Les sociétés politiques en France de 1789 à l'an II: "une machine"?', Revue d'histoire moderne et contemporaine, 36, 1989, 1, pp. 29-67.

${ }^{19}$ Jean Chagniot, 'Le Guet et la Garde de Paris à la fin de l'Ancien Régime', Revue d'histoire moderne et contemporaine, 20,1973, 1, pp. 58-71 (pp.66, 71).

${ }^{20}$ Zobel, The Boston Massacre, pp. 94-102, 109-110.
} 
Following David Garrioch we could say that colonial Boston did not lose its ability to self-organize in accordance with the principles of direct democracy. Open to all (that is, taxpaying men), assemblies of local residents made free discussion possible; 'patriotic' clubs and associations, the famous Sons of Liberty, created a sense of urban community, a coherent space defining the 'third estate', a community that challenged the British authorities - in newspapers and in the streets - and was able to bring about a physical threat to 'collaborators'. The colonial mob thus could - as Pauline Maier has written - take on the identity of the barely present institutions of the British crown, which had few available instruments of coercion, usurp the ability to replace them in solving conflicts typical of urban communities and even act as a regulator in administering justice, aware that the legal framework, pressurized by the people in the streets, allowed such a 'popular' intervention. Despite the fact that the British Riot Act of 1714 loomed on the legal horizon, providing for death penalty for rioting, and that colonial legislation often repeated its provisions (though in a milder form), the protesting Americans got used to the idea that reform, not punishment should be the result of their demonstrations. As Josiah Quincy Jr., one of the British soldiers' defence counsel, claimed, addressing the jury during the trial, 'our happy constitution' - by which he meant the colonial charters - allowed for a display of 'impatience of injuries and a strong resentment of insults'. ${ }^{21}$

In both cases of key importance in determining the dynamics of the events in the streets was the relation between the revolted 'city' and the army sent against it - that is, the degree of hostility of the protesting civilians to people in uniform professionally wielding weapons and brought in to put down the street riots. Captain Preston's small unit arrived in King Street to protect one of their own, a guard standing in front of the custom house: he was mocked and boys were throwing snowballs at him. Despite its hostility to British officials (primarily customs officers fighting smuggling), the Boston mob usually was not too aggressive; the Bostonians were able to administer punishment accord-

${ }^{21}$ Pauline Maier, 'Popular Uprisings and Civil Authority in Eighteenth-Century America', William and Mary Quarterly, 3rd series, 27, 1970, 1, pp. 3-35 (p. 26); cf. Bernard Bailyn, The Ideological Origins of the American Revolution, Cambridge, MA, 1967, pp.161-75, 209 ff.; Zobel, The Boston Massacre, pp. 48-106; Pauline Maier, From Resistance to Revolution: Colonial Radicals and the Development of American Opposition to Britain, 1765-1776, New York, 1972, pp. 52-157; John W. Tyler, Smugglers and Patriots: Boston Merchants and the Advent of the American Revolution, Boston, MA, 1986, pp. 65-114; Catherine S. Menand, 'The Things That Were Caesar's: Tax Collecting in Eighteenth-Century Boston, Massachusetts Historical Review, 1, 1999, pp. 49-77 (functions of the 'constables', pp. 51 f.). Cf. Lwww. bostonmassacre.net/trial/trial-summary4.htm> [accessed 2 October 2016]. 
ing to the logic of the 'moral economy' as described by Edward Thompson, they wanted to teach the British a lesson and humiliate them rather than kill, they were guided by the concrete rather than the abstract. Hiller B. Zobel, who was one of the first to try to describe the Boston demonstrators, thought, however, that they were a destructive element, manipulated by the conspirators, 'roughly and frequently intoxicated', a threat to the legal order in town. Richard Archer rejected the 'mindless mob' thesis and saw the demonstrators as people 'with a purpose', while Benjamin H. Irvin described them as 'people out of doors' and stressed the opposition between the street space and private dimension of relations at home. The mob preserved the collective memory of an earlier form of street riots, closer to the European charivari (in England known as 'skimmington'). ${ }^{22}$ Every 5 November - on the anniversary of an attempt to blow up Parliament in London in the early seventeenth century - two independent processions were organized in Boston, consisting primarily of craftsmen from the northern and southern parts of the city and meeting on Beacon Hill, a 'neutral' ground. A ritual fist and stick fight would end in numerous injuries and even fatalities. The participants were often masked, behaved in an arrogant manner, extorted donations from passers-by and wealthy townspeople (despite the threat of a fine, imprisonment or humiliating flogging (for the Blacks)). Carnival-like processions - initially with an anti-Catholic edge (a person dressed as a pope in red robes was driven around in a cart) - acquired a different, 'political' character a few years before the 'massacre'. Two effigies appeared on the cart: that of Admiral John Byng - executed in 1757 for causing a British defeat - probably as a mark of oppression suffered by the colonists from military (marine) courts, and of one Nancy Dawson, a dancer and a woman of easy virtue, a favourite with soldiers, which may have been the reason why she was chosen as a symbol of military usurpation of civil liberties. ${ }^{23}$ One of the leaders of the mob from 'southern neighbourhoods' and leader of street demonstrations including those with a clearly political edge - was the shoemaker (and voluntary firefighter) Ebenezer Mackintosh, a figure virtually 'born' to

${ }^{22}$ Zobel, The Boston Massacre, pp. 26-28, 46-49 and passim; Archer, As If an Enemy's Country, p. 45; Benjamin H. Irvin, 'The Streets of Philadelphia: Crowds, Congress, and the Political Culture of Revolution, 1774-1783', Pennsylvania Magazine of History and Biography, 129, 2005, 1, pp. 7-44. Cf. Edward P. Thompson, 'The Moral Economy of the English Crowd in the Eighteenth Century', P\&P, 50, 1971, pp. 76-136.

${ }^{23}$ Sherwood Collins, 'Boston's Political Street Theatre: the Eighteenth-Century Pope Day Pageants', Educational Theatre Journal, 25, 1973, pp. 401-09; Francis D. Cogliano, 'Deliverance from Luxury: Pope's Day, Conflict and Consensus in Colonial Boston, 1745-1765', Studies in Popular Culture, 15, 1993, 2, pp. 15-28. 
play in Boston the 'Parisian' role of a revolutionary agitator who leads street crowds against those in power. ${ }^{24}$

Those who contributed to the politicization of the street theatre included dissenters like the lawyer James Otis, the most radical among the American pre-revolutionary polemicists, who not only challenged the legitimacy of the imperial domination, asking why the British customs officers could, without a court order, enter a private dwelling in order to search it, but who also mused upon the basis of membership in the British commonwealth (in addition, he questioned the existence of slavery). Injured in a fight with a British customs officer, after 1768 he displayed marked mental instability, becoming nearly paranoid, but he never called for street riots to achieve political goals. ${ }^{25}$ Even the most emblematic Boston radical, Samuel Adams, shied away from calling for a 'street rebellion'. ${ }^{26}$ The resistance of the people of Boston against the Stamp Act imposed on them on 22 March 1765 (it was to enter into force in November) and the presence of the army that was to safeguard its observance inevitably led, however, to a polarization of the mood and radicalization of behaviour. On 14 August 1765 a group of about fifty 'decently clad' protesters - among them Mackintosh, said to have 'dressed neatly' - forced their way into a post office and then burnt an effigy of its manager. Twelve days later the mob, more numerous and more aggressive, burnt down and pillaged the governor's office, destroying his papers - probably to remove compromising documents concerning smuggling. Government officials became the object of the attacks: gangs from the northern and southern parts of the city joined forces and identified a common enemy. In 1766 the mob defended a smuggler at risk from customs officers; the officials were pelted with stones and threatened with 'popular punishment' - tarring and feathering, and being driven out of town - signs

${ }^{24}$ Benjamin L. Carp, 'Fire of Liberty: Firefighters, Urban Voluntary Culture, and the Revolutionary Movement', William and Mary Quarterly, 58, 2001, 4, pp. 806-09.

${ }^{25}$ Timothy H. Breen, 'Subjecthood and Citizenship: The Context of James Otis's Radical Critique of John Locke', New England Quarterly, 71, 1998, 3, p. 397. Cf. Ellen Elizabeth Brennan, 'James Otis: Recreant and Patriot', New England Quarterly, 12, 1939, 4, pp.691-725; Oliver M. Dickerson, 'The Commissioners of Customs and the "Boston Massacre"', New England Quarterly, 27, 1954, 3, p. 309; James R. Ferguson, 'Reason in Madness: The Political Thought of James Otis', William and Mary Quarterly, 36, 1979, 2, pp. 194-214; Richard A. Samuelson, 'The Constitutional Sanity of James Otis: Resistance Leader and Loyal Subject', Review of Politics, 61, 1999, 3, pp. 493-523.

${ }^{26}$ Zobel, The Boston Massacre, pp. 206, 271-72, is wrong in attributing to him the role of the instigator and 'leader' of the events of 5 March (he did not take part in the trial either). Cf. Pauline Maier, 'Coming to Terms with Samuel Adams', AHR, 81, 1976, 1, pp.12-37. 
of exclusion from the urban community. ${ }^{27}$ Another impulse that started the unrest in Boston may have been an event from June 1768 that was far from ideological dissent but close to an economic dispute between the colony and the home country. According to William Senhouse, a non-commissioned officer in the Royal Navy, 'the Sloop Liberty, belonging to one of the principal Merchants of the Town [John Hancock - P.T.D.], had been Seiz' $d$ by the order of the Commssers. Of the Customs for the breach of the Laws of Trade'. The execution of the sentence was entrusted - owing to a lack of other institutions responsible for the job - to the Royal Navy. The British officer's account of the boarding is marked by signs of 'triumphalism' because of the success achieved, yet the officer did not fail to add that 'nothwithstanding the rude reception [...] from the People of the Town we had received special [emphasis in the text - P.T.D.] directions not to fire upon them, but in the very last extremity'. Although the scuffle cost the British 'some blows and bruises of no great consequence', the irritation of the 'people of the town' was huge: they gathered in great numbers, attacked houses of customs officers, broke their windows and forced five commissioners with families and servants, sixty-seven people in total, to evacuate on board of a British man-of-war. ${ }^{28}$ The exiles demanded

${ }^{27}$ In Maryland the government distributor of stamps, attacked by the mob, had to escape on the roof of his house 'just in his shirt and trousers', while his Boston counterpart Andrew Oliver was hanged 'in effigie' on a tree named Elm of Liberty. Not only his effigy, but also his house was burnt on the night of 14 August 1765. See Bruce Ingham Granger, 'The Stamp Act in Satire', American Quarterly, 8, 1956, 4, pp. 376, 378. The English doctor Thomas Taylor reported from Savannah, in December 1775, on what happened to one of the loyal subjects of the British crown: 'about a month ago, a mob of about an hundred dissolute fellows surrounded his house, with intention to tar and feather him; upon which he came out armed, and while he was reasoning the case with them at the door, he was knocked down with the butt-end of a musquet, than laid like a calf across a horse and tied to a tree while yet sensible, and tarred and feathered. In a few days he recovered', after 'A Georgia Loyalist's Perspective on the American Revolution: The Letters of Dr. Thomas Taylor', ed. Robert S. Davis Jr., Georgia Historical Quarterly, 81, 1997, 1, p. 126. The Stamp Act was repealed on 18 March 1766, primarily due to the high costs of its enforcement and economic losses suffered by the British producers because of a boycott the colonies started in revenge. Cf. Edmund S. Morgan, Helen M. Morgan, The Stamp Act Crisis: Prelude to Revolution, London, 1953.

28 'Memoirs of A British Naval Officer at Boston, 1768-1769: Extracts from the Autobiography of William Senhouse', ed. James C. Brandow, Proceedings of the Massachusetts Historical Society, 3rd series, 105, 1993, pp. 80-81 (quotations); cf. George G. Wolkins, 'The Seizure of John Hancock's Sloop Liberty', Proceedings of the Massachusetts Historical Society, 3rd series, 55, 1921-22, pp. 239-84; David S. Lovejoy, 'Rights Imply Equality: The Case Against Admiralty Jurisdiction in America, 1764-1776', William and Mary Quarterly, 3rd series, 16, 1959, 4, pp. 478 ff.; John Phillip Reid, In a Rebellious Spirit: The Arguments of Facts, the Liberty Riot, and the Coming of the American Revolution, University Park, PA, 1979, pp. 90-126. 
protection from the army, the government sent a permanent garrison to Boston, tension rose and there were more and more incidents. Lieutenant Senhouse tried to remain detached: 'the inhabitants we found civil in general, and even hospitable but it must be confessed, that some of them were rude enough, and sometimes got into disputes with Our Officers and Seamen - circumstances not much to be wonder'd at, when we consider the discontents on one side, and probably an imperious spirit on the other'. Senhouse bemoaned the 'melancholly fate' of one of his colleagues, Lieutenant Henry Panton, who 'had boarded a merchant ship with an intent to press some of her hands when one of the Seamen, in order to prevent his purpose, stabbed the Lieutenant in the jugular vein so that he died immediately'. ${ }^{29}$ The practice of pressing people into the navy was one of recurring complaints of the inhabitants of the colony; such cases further antagonized the civilians and the military. ${ }^{30}$

In September 1769 a mob caught an informer (who told the authorities about wine smuggling), George Geyer, who was driven around the town with a lantern in hand (so that everybody could see what lay in store for snouts). In early March 1770 - a few days before the 'massacre' - more incidents took place. On 22 February a customs official mocked by some teenagers shot one of the attackers, a twelve-year-old, and a fight between the locals and soldiers ensued in the port. ${ }^{31}$ Radicalization of behaviour from grotesque games to bloodshed - as well as increasing identification of 'enemies' were elements which the Boston and the Paris mobs had in common. The stages and sequences of political radicalization in both cases evolved like a 'snowball', tension rose under the impact of publicly spoken

${ }^{29}$ See 'Memoirs of A British Naval Officer at Boston', pp. 77-78, 89. The murder took place on 11 April 1769. The officer was killed by an Irishman, Michael Corbet, who said in court that this was a case of self-defence. After a brief trial (he was defended by John Adams), he was acquitted, see Zobel, The Boston Massacre, pp. 114-31. For more on seamen (as a group susceptible to propaganda), see Jesse Lemisch, 'Jack Tar in the Streets: Merchant Seamen in the Politics of Revolutionary America', William and Mary Quarterly, 3rd series, 25, 1968, 3, pp. 371-407.

${ }^{30}$ The problem is discussed extensively in the literature, see Daniel J. Ennis, Enter the Press Gang: Naval Impressment in Eighteenth-Century British Literature, Cranbury, NJ, 2002; Nicholas Rogers, The Press Gang: Naval Impressment and Its Opponents in Georgian Britain, New York, 2007; Denver Brunsman, 'Subjects vs. Citizens: Impressment and Identity in the Anglo-American Atlantic', Journal of the Early Republic, 30, 2010, 4, pp. 557-86.

31 The funeral of young Christopher Snider (26 February) turned into a demonstration but without acts of violence (the funeral procession was led by 500 children), Dickerson, 'The Commissioners', pp. 310-11, cf. Ronald S. Longley, 'Mob Activities in Revolutionary Massachusetts', New England Quarterly, 6, 1933, 1, pp. 98-130; Maier, 'Popular Uprisings', and eadem, From Resistance to Revolution: Colonial Radicals and the Development of American Opposition to Britain, 1765-1776, London, 1973. 
and printed words - such a role was played by the account of the killing of young Snider published in the Boston Gazette - as well as a game of symbols and politically significant gestures.

We have to bear in mind, however, that - as Harriet B. Applewhite has indicated - the first civic assembly of the French body politic, the Estates General, which began its deliberations in May 1789, was not politically 'aggressive'. It was cautious about the possibility of mobilizing the street mob to exert political pressure, formulated its flagship document - the Declaration of the Rights of Man and Citizen - quite hurriedly and without any in-depth reflection, and that their 'constitutional claims' should be viewed not only from the perspective of ideological evolution and subsequent events, but even from that of the attitudes of their own, minority and reform-minded 'left'. ${ }^{32}$

Before July 1789 in Paris there were many 'local' outbreaks of discontent - manifestations of rising tension. The mob reacted in a hostile manner in August 1787 to an attempt to introduce a stamp duty (Versailles seemed to have forgotten the 'American' effects of a similar fiscal experiment). Five men were arrested for throwing stones at municipal guards on 28 September 1787 . All the men were young craftsmen. Groups of young people would chase police mouchards or spies who were allegedly legion in Paris (in fact, there were only just over 300 of them). The mob - this time reacting 'in the spirit' of charivariplayed by bonfires and burnt effigies of unpopular politicians, but on the night of 29 August 1788 five police stations were burnt and in April 1789 the plebs attacked Reveillon's paper and wallpaper factory near Paris. Among the participants and gawkers detained were a shoemaker, a printer, a decorator, people who reacted to the rumour that the rich factory owner paid his workers low wages barely sufficient to cover

${ }^{32}$ Applewhite, 'Political Legitimacy', pp. 245-73. Cf. The French Idea of Freedom: The Old Regime and the Declaration of Rights of 1789, ed. Dale Van Kley, Stanford, CA, 1997. Commenting on Mitchell B. Garrett's The Estates General of 1789. The Problems of Composition and Organization, New York, 1935, a now largely outdated study exploring the political opinions of participants in the Estates General, Harold T. Parker (in the JMH, 8, 1936, 3, pp.363-65) stressed the explosion of political pamphlets written by the deputies. Between 5 July and 25 September 1788102 pamphlets were published (1.2 per day), between 25 September and 6 November 1788 - 135 (3.2 per day), 6 November and 12 December 1788 - 132 (3.7 per day), 12 and 27 December $1788-186$ (12.4 per day), 27 December 1788 and 24 January 1789 - 216 (7.7 per day). Political pamphlets were the basic source for Rose, The Making of the Sans-Culottes, who pointed to the rising political radicalism. Robert Griffiths, Le Centre perdue: Malouet et les 'monarchiens' dans la Révolution française, Grenoble, 1988, has argued that the 'monarchist centre' of the Assembly, fixed on the model of the British constitutional monarchy, did not manage to impose its vision of a political evolution. 
the rising prices of bread. Between the street logic of workers' riots in front of Reveillon's factory and the chasing of 'whores and spies' by groups of juveniles defying authority and its representatives - this element is close to the logic of the actions of the Boston mob - there existed a shared thread of the commoners' fear of worsening working conditions as well as a clear novelty: growing politicization - anger directed against unpopular ministers known by name and against the police, a collective institution representatives of which - and their faces - were known on the level of a neighbourhood or a street. ${ }^{33}$

Unlike Boston, Paris was a city with a strong police presence, although the differences had clear markings: the Bostonians had to suffer the presence of a regular British army garrison, while the Parisians 'co-existed' with militarized units of la garde and le guet, which patrolled the city round the clock on horseback and on foot. ${ }^{34}$ The police was strengthened and supplemented by the gardes françaises regiment, the most prestigious (and most expensive) army unit, whose ceremonial and real police functions made its officers (nearly 400) and soldiers (3,342 men) involved in the everyday life of the city. Ken Alder has described the 'ideological rift' that occurred in this French guard regiment as early as June 1789. The soldiers who as late as in April had fired shots at the demonstrators in front of Reveillon's factory, refused to shoot at the mob in Versailles and on 12 July they actively supported the Parisians in their resistance against the Prince de Lambesc's cavalrymen. Two days later sixty-one of them turned up with five cannons at the Bastille. Alder has pointed out that the commander of the regiment - the unpopular 'Prussian stickler', the Duke du Châtelet - had many soldiers put into the Abbaye de Saint-Germain prison for their insubordination on 23 June. According to hostile witnesses, the fraternization between the soldiers and the demonstrators meant that the soldiers had gone over to the demonstrators' side and thus had broken their oath of loyalty. Of importance is also the fact that at least fourteen soldiers of that group of sixty-one who turned up at the Bastille, had earlier served prison sentences for infringements of the strict discipline im-

${ }^{33}$ Leonard N. Rosenband, 'Jean-Baptiste Réveillon: A Man on the Make in Old Regime France', French Historical Studies, 20, 1997, 3, pp. 506-07; Thomas M. Luckett, 'Hunting for Spies and Whores: A Parisian Riot on the Eve of the French Revolution', P\&P, 156, 1997, pp. 116-43.

${ }^{34}$ Chagniot, 'Le Guet et la Garde', pp. 58-71. The Parisian police force could be a model for entire Europe. For example, Ghent, a city with a population of up to 100,000 in the late eighteenth century, had 47 'policemen' in 1752 and towards the end of that century -200 . See Harald Deceulaer and Marc Jacobs, 'Les implications de la rue: droits, devoirs et conflits dans les quartiers de Gand (XVII ${ }^{\mathrm{e}}-\mathrm{XVIII}{ }^{\mathrm{e}}$ siècles)', Revue d'histoire moderne et contemporaine, 49, 2002, 3, p. 47. 
posed by their commander (According to Alder, in early June 1789 ten soldiers served sentences every day). ${ }^{35}$

On the night of 30 June thousands of people of Paris - the 'Parisian scoundrels' (le canaille bien tumulteuse) as the Marquise de Lostanges, observing the events at close hand, wrote - stood up for 'their' twenty-eight soldiers and forced the authorities to release them. It could be argued once again, as Pierre Caron did over a century ago, that 'popular justice', which triumphed at the time - Louis XVI pardoned them for their offences the following day - had the hallmarks of a 'revolution', and the privileged military unit in fact ceased to perform its functions as the royal gendarmerie in the capital. The king's pardon was - in political terms - an unforgivable mistake. It is, therefore, not surprising that Mme de Lostanges, the daughter and wife of loyal officers, who commented on the situation in Paris on an on-going basis, claimed shortly after that 'It is a shame for our nation that the foreign troops are more faithful to the king of France than the French guards', while an analysis by the Duke de Liancourt, who on 15 July replied to the king surprised by the events: 'Sire, this is not a riot, it is a revolution', summed up the disintegration of authority, a process visible to all. ${ }^{36}$

In Boston the relationship between the army and the civilians was clearer - two British regiments were to support the work of the monarchy's civilian bureaucratic apparatus, with the soldiers living in barracks; the officers of the gardes françaises, on the other hand, had their lodgings in the city - discipline in the regiments was not at risk of external propaganda and the army - which was very unpopular - tried to keep away from civilian affairs. The effects of the shots fired by Preston's unit were judged according to civilian, municipal laws, the effects of the charge by the Germans from Colonel de Lambesc's regiment - much less bloody - were immediately categorized as a crime against the people to be judged by 'revolutionary justice'. In Boston the officer and the soldiers gave themselves in to civilians and were put in the city prison. Yet despite such a serious crisis

${ }^{35}$ Ken Alder, 'Stepson of the Enlightenment: the Duc du Châtelet, the Colonel who “Caused” the French Revolution', Eighteenth-Century Studies, 12, 1998, 1, pp. 1-18; Jean Chagniot, “'Si le roi était monté à cheval et qu'il se fût montré à l'armée” (Rivarol): Les chances de la solution militaire en Juin et Juillet 1789', Annuaire-Bulletin de la Société de l'histoire de France, 1988, pp. 23-32.

${ }^{36}$ Pierre Caron, 'Un témoignage sur les événements de juillet 1789 (lettres de $\mathrm{M}^{\mathrm{me}}$ de Lostanges)', RevHist, 116, 1914, 2, p. 300 (on the release of the soldiers), p. 302 (on the shame: 'à la honte de notre nation, les troupes étrangères sont plus fidèles au roi de France que les gardes-françaises'); idem, 'La tentative', pp. 19, 653-54, Comment attributed to Laincourt after Simon Schama, Citizens: A Chronicle of the French Revolution, New York, 1989, p. 8. 
no escalation ensued: the troops were withdrawn from the city, the angry mob did not demonstrate. Even the funeral procession of the victims, in which thousands, at least half of the adult population of the city, took part, did not turn into riots. As Neil L. York has stressed, both sides avoided confrontation, relying on the legal system, which guaranteed a fair, that is harsh, sentence, as expected by the 'radicals', an expectation shared by the 'street mob'. The fundamental characteristic of the American - long 'revolutionary process' was self-limitation of both sides of the conflict despite the increasing temperature of political rhetoric - in the hope that the legal mechanisms to which both London and the colonists were used would make it possible to find compromise solutions. ${ }^{37}$ The key to understanding the sequence of events in Paris and in Boston seems to be the way in which political opponents were able to use the 'revolutionary narrative' and the existing legal order to achieve their goals. As Roger Chartier has written, ways of taking over, making use of and interpreting various elements of culture by specific groups within society determine the capacity to change its basic parameters. ${ }^{38}$ The aggrieved people referred to the justice system, imposing new forms of its operation in Paris and trusting in the existing common law system in Boston. A sense of 'revolutionary' (in Paris) and impartial (in Boston) justice was to legitimize the events and give a political meaning to the riots.

Both these processes drew on the notion of 'revolutionary justice', a key term that described, in terms of law enforcement - and society's expectations - the relations between those who had hitherto been in power (and who were under threat) and those who now wielded that power. The birth of the citizens' sense of having the right to pass judgements can be followed in France on many levels. Let us mention three. As Michael Kennedy has shown, citizens' associations, set up in the provinces in great numbers, threatened postmen with court action, because mail from the capital did not reach them on time! Acquiring knowledge of the events in the capital allowed provincials to formulate their own opinions and take their own decisions. On another level of 'appropriating' the law, the theatre-going public, freed (for some time) from the presence of spies and guardsmen, demanded influence on the repertoire and expressed its moods in a way that determined not only the artistic

${ }^{37}$ Zobel, The Boston Massacre, p. 215; Neil L. York, 'Rival Truths, Political Accommodation, and the Boston "Massacre"', Massachusetts Historical Review, 11, 2009, pp. 57-95; idem, 'Imperial Impotence: Treason in 1774 Massachusetts', Law \& History Review, 29, 2011, 3, pp. 657-701.

${ }^{38}$ Roger Chartier, 'Text, Symbols, and Frenchness', in idem, Cultural History: Between Practices and Representations, transl. Lydia G. Cochrane, Ithaca, NY, 1988, p. 102. 
success of productions. Finally, when it came to international relations, the need to reject what was 'old' prompted the 'new' France to seek to redefine the way diplomacy functioned, renouncing the 'secrecy' practised by aristocrats and questioning the treaties they had signed. ${ }^{39}$ The people were also interested in the very process of administering justice 'in the new way'. On 21 October 1789 in Paris the city council established a comité des recherches, a police and investigative body serving as political police, which was supposed to send the results of its deliberations to the 'new' Châtelet, the most important magistrates' court (which had existed earlier). The first task of the committee was to investigate whether the people of Paris were at risk of a 'counter-revolutionary conspiracy' halted by the events of 12 July: 'The ax and the cord are excellent remedies for quieting and calming the resentments of the People', wrote Jacques Brissot, the best known member of the committee, with his usual flamboyance..$^{40}$ The fear of the royal court's secret machinations was common. Clarke Garrett has demonstrated that even if the notion of 'counter-revolution' was very fresh (having originated only in September 1789) - as was its antinomy, that is 'revolution' - the feeling that there existed a conspiracy that would thwart the reforming (a term used deliberately to avoid writing 'revolutionary') efforts of the nation seems to have been virtually built into all events regarded as groundbreaking by the contemporaries. The new authorities resorted, therefore, to a dramatic rhetoric: possible murderers -

${ }^{39}$ On the 'new' phenomenon of reading political press, see Michael L. Kennedy, 'Les clubs des Jacobins et la presse sous l'Assemblée national 1789-1791', RevHist, 264, 1980, 1, pp. 49-63; idem, 'The Jacobin Clubs and the Press: "Phase Two"', French Historical Studies, 13, 1984, 4, pp.474-99. One of the authors who appealed to the tastes of the 'revolutionary public' for a long time was Jacques-Marie Boutet known as Monvel (1745-1812), a Comédie Française actor (in 1770-81), then director of a French troupe in Stockholm, and in 1789-99 the seventh most popular playwright, author of, for example, the comedy Le Chêne patriotique, ou la Matinée du 14 juillet, which referred to the 'July events'. Cf. Roselyne Laplace, Monvel. Un aventurier du théâtre au siècle des Lumières, Paris, 1998. On the revolutionary 'redefinition of diplomacy', see Linda Frey and Marsha Frey, "The Reign of Charlatans is Over": The French Revolutionary Attack on Diplomatic Practice', JMH, 65, 1993, 4, pp. 706-44.

${ }^{40}$ Quoted by Barry M. Shapiro, 'Revolutionary Justice in 1789-1790: The Comité des Recherches, the Châtelet, and the Fayettist Coalition', French Historical Studies, 17, 1992, 3, p. 660. The problems with establishing new municipal institutions were discussed already by Henry E. Bourne, 'Improvising a Government in Paris in July 1789', AHR, 10, 1905, 2, pp. 280-308. Brissot's multidimensional personality has long attracted historians' attention, see Robert C. Darnton, 'The Grub Street Style of Revolution: J.-P. Brissot, Police Spy', JMH, 40, 1968, 3, pp. 301-27; idem, 'The Brissot Dossier', French Historical Studies, 17, 1991,1, pp. 191-205; Frederick A. de Luna, 'The Dean Street Style of Revolution: J.-P. Brissot, Jeune Philosophe', French Historical Studies, 17, 1991, 1, pp. 159-90; Simon Burrows, 'The Innocence of Jacques-Pierre Brissot', HJ, 46, 2003, 4, pp. 843-71. 
commanders rather than privates - were going to meet popular justice, which, surprisingly but necessarily, took the form of a trial conducted according to the principles of the 'old' monarchic criminal procedure. Changes were happening too quickly for the legislator - the National Assembly - to be able to introduce new forms of judging and punishing (a new criminal code was not adopted until 1791). According to the old regime's principles of criminal proceedings, the procedure was closed and non-public, judges used written testimonies, questioning the witnesses and the accused separately, carefully weighing the evidence in order to formulate the sentence..$^{41}$ The ideological imperative of the 'revolution' - a need to find culprits - clashed with institutional inefficiency.

Indicating and judging the 'July conspirators' was necessary, because it emphasized the role of - little known - 'July heroes' and showed that the 'new justice' was fundamentally different from the one that had prevailed over the French until July 1789 and had failed on the streets of Paris. A measure of the way of thinking at the time - typical and firmly rooted in the tradition of absolutism - was the fact that the idea of conspiracy was not associated with the person of the king. Publications issued in print after the fall of the Bastille mentioned that women had urged their husbands to get out of their houses, because, as they said, an attack on the symbol of power was an attack on the king ('c'est pour le roi'). We should use similar categories to understand the intent of a delegation of the residents of the Faubourg Saint-Antoine - active participants in the attack - to pay their respects to Louis XVI already on 16 July and the resolution of Paris electors, who voted on the $17 \mathrm{July}$ to erect a monument to the king to replace the loathsome jail. ${ }^{42}$ The man to be brought to court was Baron Besenval, min-

${ }^{41}$ Bernard Schnapper, 'Le jury criminel', in Un autre Justice: Contributions à l'histoire de la justice sous la Révolution française (1789-1799), ed. Robert Badinter, Paris, 1989, pp. 149-70; Richard M. Andrews, Law, Magistracy, and Crime in Old Regime Paris, 1735-1789, Cambridge, 1994, vol. 1: The System of Criminal Justice, pp. $417 \mathrm{ff}$. The public circulation of legal texts associated with the most widely 'publicized' trials is discussed by Sarah Maza, Private Lives and Public Affairs: The Causes Celebres of Prerevolutionary France, Berkeley, CA, 1996. On the 'obsession of openness' and need to supervise all spheres of public and private life as a new social directive, see Susan Maslan, 'Susannah at Her Bath: Surveillance and Revolutionary Drama', Eighteenth-Century Studies, 34, 2001, 3, pp. 421-39. On the constant fear of a 'counter-revolution' and possibilities of using this stereotype, see Clarke Garrett, 'The Myth of the Counterrevolution in 1789', French Historical Studies, 18, 1994, 3, pp. 784-800. Cf. Munro Price, The Road from Versailles: Louis XVI, Marie Antoinette, and the Fall of the French Monarchy, New York, 2004.

${ }^{42}$ For more on the delegation and the resolution, see Funck-Brentano, 'La Bastille', p. 302. The five-person management included Pierre Lacretelle (who quickly withdrew), Jacques-Pierre Brissot, Jean-Philippe Garran de Coulon (author of most re- 
ister and commander-in-chief of the troops surrounding Paris in July 1789, who had ordered Prince Lambesc's German regiment to 'clear' the Tuileries Gardens of the demonstrators. Testimonies of eighty-five witnesses to the events of 12 July were collected. The investigation lasted a long time, but on 29 January 1790 the decision was taken to release Besenval without charging him. The 'revolutionary' justice system turned out to be lenient - or, perhaps, helpless and caught in the trap of old forms, and was unable to meet society's new expectations.

In August 1789 Joseph Garat spoke of the need for a new quality in the revolutionary perception of the law and displayed the naive optimism of the moderate wing of the 'July patriots': 'let us mark our own happy epoch by branding our justice with the sentiments of generosity and moderation which do honour to our century'. ${ }^{43}$ A similar outcome and a triumph of an enlightened sense of 'progress' was the introduction - into the 1791 criminal code - of the principle of carrying out death sentences by means of a 'humanitarian' machine built by Antoine Louise according to a design by Dr Guillotin. The device, which was to guarantee equality in the face of death, was used for the first time only in April 1792 (the victim was a common criminal). Until that moment sentences had been carried out 'in the old way', by means of the executioner's sword. The helplessness of the 'new' justice or, rather, confusion of systems and lack of a clear answer as to whom it was responsible - the king or the nation - led to a situation in which, for example, instead of the 'obvious' culprits, Besenval and the minister of defence, the Duke de Broglie (who managed to emigrate as early as on 16 July), the death sentence was imposed (on 19 February 1790) on the Marquis de Favras, whom a complex web of intrigue linked both to the court and to some leaders of 'the people' (Mirabeau). ${ }^{44}$

ports) and hitherto little known lawyers Pierre-Louis Agier, Nicolas Oudart and Alexandre Perron, see Shapiro, 'Revolutionary Justice', pp. 659-60; idem, Revolutionary Justice in Paris 1789-1790, Cambridge, 1993. Patrice Gueniffey, La Politique de la terreur, Paris, 2000, p. 143, identified Brissot's attitude as early as in 1789 as willingness to take extreme measures.

${ }^{43}$ Quoted after Shapiro, 'Revolutionary Justice', p. 657 f. Cf. George A. Kelly, 'From Lese-Majeste to Lese-Nation: Treason in Eighteenth-Century France', Journal of the History of Ideas, 42, 1981, 2, pp. 281-82.

${ }^{44}$ When on 1 December 1789 Joseph Guillotin praised his invention, which apparently worked 'like thunder', in front of the Assembly, the deputies greeted his speech with a roar of laughter. Yet the idea of 'democratizing the infliction of death' was favourably received. See Arthur I. Applebaum, 'Professional Detachment: the Executioner of Paris, Harvard Law Review, 109, 1995, p. 463; Janes, 'Beheadings', pp. 32-33. Daniel Arasse, La Guillotine et L'Imaginaire de la Terreur, Paris, 1987. The justice system did not become efficient enough until the times of the Republic. Between 6 April 1793 and 27 July 1794 the revolutionary tribunal tried 4,021 cases of treason, passing death 
Thus the investigation of the July conspiracy ended in failure: what was lacking were both victims of 'despotism' and those guilty of the shedding of their blood. A similar failure lay in store for the prosecution in Boston: two soldiers - murderers according to the patriotic propagan$\mathrm{da}$ - were convicted of manslaughter but not of murder, and were sentenced to having their thumbs (!) branded with a hot iron; six were acquitted. Outside the courtroom no outraged demonstrators waited for them to administer the people's version of the punishment. ${ }^{45}$ The Paris testimonies revealed an unclear picture and uncertain views: they confirmed unrest on the streets - a state which does not yet signal a revolution, they provided accounts of the riots as well as surprise at the appearance of the army, they also confirmed the omnipresence of rumours. A Parisian lady returning from a Sunday outing to the countryside mentioned that "my servant told me that I could not go to the play, as the theatres were all shut by orders from the police, that Paris was all in confusion and tumult, and that the Prince de Lambesc had entered the gardens of the Tuileries and put all the people to flight, that he had killed an old man'. ${ }^{46}$ A passer-by, François Drounin, was walking with his wife and daughter along the Champs-Élysées, when he heard shots and saw a dragoon troop. His observations were confirmed by seventy-two out of seventy-three witnesses, a further fourteen mentioned stones being thrown at soldiers (five mentioned the throwing of chairs and stools), and just as many spoke of warning shots fired into the air. More importantly, as another Sunday stroller reported, it was said that 'Monsieur Prince de Lambesc was massacring everybody at the place Louis XV'. The function, well-recognized by sociologists, of gossip, information that cemented the

sentences on 2,585 people (64 per cent). See Carla Hesse, 'La preuve par lettre. Pratiques juridiques au tribunal révolutionnaire de Paris (1793-1794)', Annales. Histoire, Sciences Sociales, 51, 1996, 3, pp. 629-42, especially pp. 630-31. The revolution also led to the emergence of varied ideas of the body: it created a heroic image of its own martyrs (for example, Marat) and denigrated the bodies of its enemies (for example aristocrats), see Antoine de Baecque, 'Le sang des héros. Figures du corps dans l'imaginaire politique de la Révolution française', Revue d'histoire moderne et contemporaine, 34, 1987, 4, pp. 553-86; Ludmila Jordanova, 'Medical Meditations: Mind, Body and the Guillotine', History Workshop, 28, 1989, pp. 39-52. On Favras's conspiracy, see Henri Carre, La noblesse de France et l'opinion publique au XVIII siècle, Paris, 1920, pp. 413-19.

${ }^{45}$ Zobel, The Boston Massacre, pp. 294-300.

${ }^{46}$ Journal of My Life during the French Revolution by Grace Dalrymple Elliott, London, 1859, repr. The Rodale Press, London, 1955, p. 1, critical Polish edition and translation Szkotka w Paryżu. Pamiętnik Grace Elliott 1789-1794, ed. and transl. Paweł T. Dobrowolski, Warsaw, 2008, p. 43. On gossip as a communication method, see Edith B. Gelles, 'Gossip: An Eighteenth-Century Case', Journal of Social History, 22, 1989, 4, pp. 667-84; Robert B.P. Paine, 'What is Gossip About? An Alternative Hypothesis', Man, 2, 1967, 2, pp. 278-85. 
circulation of specific content, meant that attempts at a clear-headed assessment of the situation proved meaningless: 'they say he killed many people,' the Marquise de Lostanges wrote to her husband, 'but it's not true: they fired only once, and in the air to frighten the coquins, and to let decent people, who were taking their walk, to depart'. The massacre that did not happen became a public and 'media' fact. ${ }^{47}$ The consequences of the 'unfinished' revolution of July 1789 were very serious, however, and concerned - as Samuel F. Scott has argued - the unresolved dispute over the legitimization of power. At the root of the bloody riots in Marseille and Lyon, the revolt of the army and the 'massacre' in Nancy as well as the fratricidal fighting in Nîmes and across Languedoc in 1790 was not so much the problem of the 'royal' troops being stationed in cities governed by 'patriots' or rivalry between the 'old' - and demoralized - army and the 'new', revolutionary National Guard, but a conflict of civic attitudes and expectations of further democratization of the country - expectations addressed to the authorities in Paris. At the risk of committing the sin of historical presentism, the July events demonstrated that the idea of a revolution understood as an offer of change had not been entirely consumed and that a hybrid justice system was quickly replaced by 'savage justice'. The latter was popular justice generated by fear and fury, as described by the English writer Helen Mary Williams, a witness to the September massacres of 1792. Nothing of the sort happened in Boston after the trial; there were only some posters, as the short-term goal - driving the army out of the city (and not a revolution!) - had been achieved. ${ }^{48}$

of crucial importance in 'depicting' a revolution is the media dimension of the riots which initiated it. It should be noted that colonial readers, in this case those in Boston, had access to - and were able to read rationally - a far greater variety of 'political' publications than their French counterparts. Even such seemingly apolitical publications as colonial calendars or almanacs that reached thousands of people began, after 1760 , to provide information not only about the weather and rural medicine, but also about 'national' problems, referring, for example, to

${ }^{47}$ For example, 'On disait qu'il avait tué beaucoup de monde, mais c'est faux; il a fait faire une [dé]charge, mais en l'air, afin d'effrayer les coquins, et de laisser sortir les honnêtes gens qui se promenaient', after Caron, 'Un témoignage', p. 309; Spagnoli, 'The Revolution Begins', p. 485.

${ }^{48}$ Zobel, The Boston Massacre, pp. 298-99, Samuel F. Scott, 'Problems of Law and Order during 1790, the "peaceful" Year of the French Revolution', AHR, 80, 1975, 4, pp. 859-88. This motive in Williams' letters (Helen Maria Williams, Letters from France, 4 vols, London, 1790-93) has been analysed by Howell, 'Burke, Paine, and the Newspapers', pp. $396 \mathrm{f}$. On the disintegration of the army and decisional atrophy of the royal camp, see Chagniot, "'Si le roi"', pp. $26 \mathrm{ff}$. 
a sense of patriotism of farmers and fundamental principles of justice. In the face of growing resistance to the import of English goods. John Hutchins's 1764 New York almanac suggested to the readers, 'when you incline to drink Rum, fill the glass half with Water. Thus at the Year's End there will be 200,000 pounds more Money in your Country'. ${ }^{49}$ The appeal to frugality as a mechanism of defence against the economic domination of the home country shows how important in generating a feeling of uncertainty and threat among the American colonists was the fact that many of them were 'in the pocket' of British creditors, and that in 1776 all colonies - according to Richard Sheridan's findings - were in debt to the tune of nearly three million pounds (this however concerned primarily the 'rural' South). ${ }^{50} \mathrm{The}$ anger of the Boston mob - clearly in evidence a few days after the shooting - did not turn into a call for an 'uprising', but assumed the form of a 'pen polemic', a fierce press campaign against the 'murderers in uniforms', whose trial was as yet seven months away. At that time a deliberate propaganda campaign was in operation, including written testimonies of ninety-six witnesses, published at the city's expense. Forty copies were sent to London, to the offices of government representatives; accusations of military tyranny and heartless shooting of the innocent were bandied about. $^{51}$

We should point out here one crucial difference which we have to take into account when describing the 'dynamics' of both revolutions: the French and the American. The latter was, as it were, 'shifted in time' - the events in the colonies were reported in London, by means of letters, press accounts, printed pamphlets, personal and official reports after a delay of several weeks, the time it took to cross the Atlantic. London's reactions also reached the other side of the Atlantic after a similar delay. The events of 5 March, described in detail in a private letter of 12 March, became known in the metropolis in April and already at that time a narrative began to take shape and in it soldiers 'were seen parading through the streets with their drawn cutlasses and bayonets abusing and wounding numbers of the inhabitants'. Readers in London were presented with a depiction of a scene in which 'a soldier was brandishing a broadsword of an

${ }^{49}$ Quoted by Allan R. Raymond, 'To Reach Men's Minds: Almanacs and the American Revolution, 1760-1777', New England Quarterly, 51, 1978, 3, p. 374.

${ }^{50}$ Richard B. Sheridan, "The British Credit Crisis of 1772 and the American Colonies', Journal of Economic History, 20, 1960, 2, pp.161-86 (territorial distribution of debt, see p.167). Cf. Staughton Lynd and David Waldstreicher, 'Free Trade, Sovereignty, and Slavery: Toward an Economic Interpretation of American Revolution', William and Mary Quarterly, 68, 2011, 4, pp. 597-630.

${ }^{51}$ London Magazine, 39, 1770, pp. 222-23. 
uncommon size against the walls out of which struck fire plentifully'. ${ }^{52}$ Similar propaganda was the objective of the printing in London of a sermon delivered by Reverend John Lathrop, pastor of the second Boston Church, on the Sunday following the riots. The title of the sermon was significant: 'Innocent Blood crying to God from the streets of Boston' and was quite coldly received by the London reviewers. ${ }^{53} \mathrm{~A}$ calmer tone - although there was still a mention of 'outrage and massacre' - was that of a pamphlet edited by the Boston 'patriots' and entitled A Short Narrative of the Horrid Massacre. It told the story of oppression going back to 1765, spoke of 'His Majesty's subjects' who had been killed (three) and of the wounded who would 'soon die'; it consolidated a narrative in which the culprits were clearly indicated ('soldiery being to blame'). Its author, the well-known lawyer James Bowdoin, a political conservative who, however, did not disdain aggressive, 'plebeian' journalism, argued that the military occupation of Boston was an instance of lèse-majesté; he demanded that the soldiers be withdrawn, referred to the foundations of the British rule of law (including the Magna Charta) and believed the 'massacre' to have been a military provocation and the culprits to be traitors. The pamphlet was also reprinted by a publishing house in London, but its reviewers in the capital limited themselves to summing up the entire matter as an 'unhappy affair' sufficiently described in the daily newspapers, adding that, given the turmoil in Boston, eleven victims were not that many and that it 'could have been much worse'. The version of events formulated by the Boston patriots consolidated the common picture of a division into 'us' and 'them', accepted by the American colonists, and created a historical canon of the March events. ${ }^{54}$

${ }^{52}$ Ibid.

${ }^{53}$ The full title was: 'Innocent Blood crying to God from the streets of Boston. A sermon occasioned by the horrid murder of Messrs. Samuel Gray, Samuel Maverick, James Caldwell, and Crispus Attucks, with Patrick Carr, since dead and Christopher Monk, judged irrecoverable and several others being wounded, by a Party of Troops under command of captain Preston: On the $5^{\text {th }}$ of March 1770, and preached the Lord's Day following By John Lathrop AM pastor of the second Church in Boston'. A review was limited to the following observation: 'it were almost needless to make any comment upon this religious production, which is necessarily animated with political altercation'. The reviews were printed in Town \& Country Magazine, 2, 1770, p. 267; London Magazine, 39, 1770, p. 268.

${ }^{54}$ Francis G. Walett, 'James Bowdoin: Patriot Propagandist', New England Quarterly, 23, 1950, 3, pp.320-38. A perfunctory review of the pamphlet in Monthly Review, 42, 1770 , p. 415, full text in, for example, London Magazine, 39, 1770, pp. 249-51, see also Oxford Magazine, 4, 1770, pp. 174-78 with full reprint from the Boston press and witness testimonies. 
American historians have long been occupied by the question why the revolution in the colonies was relatively mild. ${ }^{55}$ Why cannot we, when describing the 'revolutionary process' in America, paint, as Albert Soboul did for France, a great panorama of protest, of a 'class-oriented', popular, 'proletarian' and plebeian revolution? The anonymous letter from Boston published in London contained a list of names of the victims. Among the wounded we will find David Parker, a wheelwright's hand, John Green, a tailor, Patrick Carr, a tailor making leather trousers, Edward Payne, a merchant, Christopher Monk, a seventeen-year-old assistant shipwright, and Robert Paterson, a seaman. ${ }^{56}$ Were the Boston craftsmen not sufficient substitutes of the demonstrators from the working class suburbs of Saint-Antoine and Saint-Michel? Why is it so difficult to point to a colonial Marat and why did the barbarity of the massacre of September 1792 not have any American antecedents? ${ }^{57}$ In what categories can we, therefore, compare the American revolution with its younger, French variety, identifying the sociological parameters thanks to which we could find the colonial 'third estate', so important to the Paris events? In this we should en-

55 The question was formulated by Gordon S. Wood, The Creation of the American Republic, 1776-1787, Chapel Hill, NC, 1969.

${ }^{56}$ London Magazine, 39, 1770, pp. 222-23.

57 The classic thesis concerning the role of the sans-culottes: Albert Soboul, Les Sans-culottes parisiens en l'an II: Mouvement populaire et gouvernement révolutionnaire, 2 juin 1793-9 thermidor an II, Paris, 1962 (abridged English edition: The Parisian Sans-Culottes and the French Revolution, 1793-4, Oxford, 1964, and The Sans-Culottes: The Popular Movement and Revolutionary Government, 1793-1794, transl. Remy I. Hall, Princeton, NJ, 1980). When it comes to the September massacre, of value is still Pierre Caron, Les Massacres de septembre, Paris, 1935. See Thompson, 'The Moral Economy of the English Crowd', reprint in idem, Customs in Common, New York, 1993. On the seamen's radicalism: Lemisch, 'Jack Tar', and 'The American Revolution Seen from the Bottom Up', in Towards a New Past: Dissenting Essays in American History, ed. Barton J. Bernstein, New York, 1968, pp. 3-45; see also George Rude, The Crowd in History, 1730-1848, New York, 1964, pp. 19-46. The history of the 'mob' in America has acquired a vast literature, see Arthur M. Schlesinger Jr., 'Political Mobs and the American Revolution, 1765-1776', Proceedings of the American Philosophical Society, 99, 1955, 4, pp. 244-50; Richard M. Brown, 'Violence and the American Revolution', in Essays on the American Revolution, ed. Stephen G. Kurtz and James H. Hutson, Chapel Hill, NC, 1973, pp. 81-120; Pauline Maier, 'The Charleston Mob and the Evolution of Popular Politics in Revolutionary South Carolina, 1765-1784', Perspectives in American History, 4, 1970, pp. 173-96; eadem, From Resistance to Revolution: Colonial Radicals and the Development of American Opposition to Britain, 1765-1776, New York, 1974; Alfred F. Young, 'English Plebeian Culture and Eighteenth-Century American Radicalism' in The Origins of Anglo-American Radicalism, ed. Margaret Jacob and James Jacob, London, 1984, pp. 185-212; Barbara C. Smith, 'Food Rioters and the American Revolution', William and Mary Quarterly, 41, 1994, 1, pp. 3-38; Paul A. Gilje, The Road to Mobocracy: Popular Disorder in New York City, 1763-1834, Chapel Hill, NC, 1987. 
tertain no illusion that the French Estates General (1,318 deputies in total) were a group of radicals ready to overthrow the existing regime immediately. Only about 10 per cent of the deputies expressed a conviction - radical, given the mood in 1789 - that the Estates represented the 'sovereignty of the people' and only 19 per cent were ready to use the people as an instrument of political pressure against the monarchy. ${ }^{58}$

A closer look at the American 'revolutionary mobs' reveals their limited enthusiasm for destroying the established order. Such an examination points above all to a desire to 'take care of' current and pressing ills as well as a mechanism solving local conflicts, and to trust in the local institutions responsible for maintaining order. The plundering of the governor's residence in Boston was condemned even by the most 'radical' authors of anti-British political rhetoric, while the fights between seamen and British press gang members had their own logic in which loyalty to the colonial patrons was not the most important element, although in patriotic propaganda they were presented as battles to defend civil liberties. Even extreme - in American terms - radicals remained moderate and respected the legal order. Colonial 'democracy' - the style and rules of society's functioning more than a political paradigm - had a social dimension, ready to protest but hostile to a 'revolution'.

Manifestations of resistance to the Stamp Act, which so enraged the American colonists, were copied by their neighbours from the British

${ }^{58}$ Furet and Halévi, 'L'année 1789', pp. 3-24; cf. Isaac Kramnick, 'Reflections on Revolution: Definition and Explanation in Recent Scholarship', History and Theory, 11, 1972, pp. 26-63; Perez Zagorin, 'Theories of Revolution in Contemporary Historiography', Political Science Quarterly, 88, 1973, 1, pp. 23-52; Applewhite, 'Political Legitimacy', pp. 254, 258. Tackett, Becoming a Revolutionary, pp. 75 f. In 1790 there were 152 Societies of the Friends of the Constitution (Jacobin Clubs) in France. In 1791 its members constituted about 4 per cent of the country's adult population. In the Marseilles club typical of the whole country -24 per cent of the members represented independent professions, 17 per cent represented shopkeepers and 9 per cent represented merchants. See Michael L. Kennedy, The Jacobin Clubs in the French Revolution: The First Years, Princeton, NJ, 1982, pp. 225 f. Revolutionary (leftist) radicalism, identified in France with the Jacobins' political evolution, has a rich history of scholarship (F. Furet's critical opinion draws on the rich tradition going back to Albert Mathiez and Georges Lefebvre); views continue to diverge - for Ferenc Feher, The Frozen Revolution: An Essay on Jacobinism, Cambridge and Paris, 1987, Jacobinism remains a 'break with the revolution' and a change in the political discourse leading to state totalitarianism, but, for example, Jean-Pierre Gross, Fair Shares for All: Jacobin Egalitarianism in Practice, New York, 1997, p. 17, has tried to present the Jacobins as neo-liberals, as reformers (and not revolutionaries), among whom only 20 per cent (like Fouché or Javouges) were 'hard-line terrorists'. Cf. Lucien Jaume, Le Discours jacobin et la Démocratie, Paris, 1989; Patrice Higonnet, Goodness beyond Virtue. Jacobins during the French Revolution, Cambridge, MA, and London, 1998; Gueniffey, La Politique. 
islands in the Caribbean. In Basseterre, the capital of the small island of St Kitts, several hundred disenchanted people gathered in an inn on 31 October 1765 and then went, accompanied by the sound of drums, to the house of the 'stamp officer', who - despite his illness - was put on a horse, beaten up and expelled from the town. The same gestures of protest and symbols (such as the burning of effigies) as in Boston were used by the Caribbean mob (which consisted only of white people, while the official's life was apparently saved by black slaves). Those participating in the riots included plantation stewards and entrepreneurs for whom - as Andrew O'Shaughnessy has calculated - the requirements stemming from the Act were twice as expensive as for the North American demonstrators. ${ }^{59}$ Among the protesters in the Caribbean were merchants and planters (including those who consumed the profits from their overseas estates in London). In North America - poorer per capita than the owners of latifundia in Antigua or Barbados - the social profile of the protesters was more similar to the urban model defined by the participation of small entrepreneurs and shopkeepers.

The professional composition of the Boston Masonic Lodge of St. Andrew (from 1752-75) shows that 26.7 per cent of the members were merchants - who determined the economic success of the urban community - further 36.7 per cent represented people of the sea, skippers and captains of ships, 19.1 per cent were craftsmen and only 4.2 per cent represented independent professions (doctors and teachers). ${ }^{60}$ A man who fought to strengthen his social status, a confirmed democrat and believer in social equality, Dr Thomas Young - seemingly a model American Marat - was on the streets of Boston on the night of 5 March, calling the mob not to attack the British barracks but to disperse and go home. Those involved in physical combat were the 'true' sons of the street associated with citizens' self-help organizations in the city (for example firefighting squads), like the barber Benjamin Burdick and the carpenter Theodore Bliss. ${ }^{61}$ Regarded as a radical, indefatigable polemicist and organizer of urban resistance (in Boston) against the British 'tyranny', Samuel Adams - said to have taught his dog Queue to bark at every red coat of a British soldier - openly condemned the mob's attack on Governor Hutchinson's house of 26 August 1765 and refused to inspire street demonstrations. For the sake of accuracy, we should bear

${ }^{59}$ Andrew J. O'Shaughnessy, 'The Stamp Act Crisis in the British Caribbean', William and Mary Quarterly, 51, 1994, 2, pp. 203-26.

${ }^{60}$ Steven C. Bullock, 'The Revolutionary Transformation of American Freemasonry, 1752-1792', William and Mary Quarterly, 47, 1990, 3, p. 360.

${ }^{61}$ Carp, 'Fire of Liberty', p. 810. 
in mind, however, that the mob gathered at the Bastille demonstrated 'peacefully' until it was shot at from the walls of the fortress. ${ }^{62}$ Even manifestations of 'working class' resistance - that is resistance motivated primarily by economic factors - and explosion of hostility had different overtones in Anglo-American than in French culture. The best organized profession in England were the London weavers, thousands of craftsmen living in the eastern suburbs, who were able to organize several large - for London - demonstrations, forcing favourable pay regulations to be introduced. The biggest riots from 1764-69 involved the use of the army to pacify the weavers, yet when they were tried for breaking in and destroying looms - only a few people were convicted. In the first few months following the capture of the Bastille, textile workers (30 per cent among the arrested demonstrators) in industrial towns in Normandy caused large scale damage, destroying and burning, among others, modern weaving machines imported from England. ${ }^{63}$

The rebellious Americans did not send anyone to the guillotine; instead, they preferred to write lengthy constitutional polemics. Even the 'storming' of the residence of the British governor did not turn into an insurrection, the 'street leader' Mackintosh did not head a popular uprising, and the mob did not - as it did in Paris (and, for example, in Warsaw in 1794) - resort to hanging people from lamp posts, and late at night went home. Despite a considerable difference in the size of their populations, the biggest American cities, Boston and Philadelphia, displayed some similarities to Paris in terms of their occupational and social structure. Labour market relations were similar too: manual workers predominated in Paris and in America ${ }^{64}$ Despite the fact that in the eighteenth

${ }^{62}$ Zobel, The Boston Massacre, p. 214, believes that Adams was prepared for the use of force in the streets, but see Lucas, 'The Crowd and Politics', p. 435; Edward Countryman, 'The Problem of the Early American Crowd', Journal of American Studies, 7, 1973, pp.77-90; Pauline Maier, 'Reason and Revolution: The Radicalism of Dr. Thomas Young', American Quarterly, 28, 1976, 2, pp. 229-49; eadem, 'Coming to Terms', pp. 17, $24 \mathrm{ff}$.

${ }^{63}$ Alessandro Nuvolari, 'The Machine-Breakers and the Industrial Revolution', Journal of European Economic History, 31, 2002, 2, pp. 393-436; Jeff Horn, 'Machine-Breaking in England and France during the Age of Revolution', Labour/Le Travail, 55, 2005, pp. 143-66.

${ }^{64}$ Billy G. Smith, 'The Material Lives of Laboring Philadelphians, 1750 to 1800', William and Mary Quarterly, 38, 1981, 2, pp. 163-202; idem, 'Inequality in Late Colonial Philadelphia: A Note on Its Nature and Growth', William and Mary Quarterly, 41, 1984, 4, pp. 629-45; Philip S. Foner, Labor and the American Revolution, Westport, CT, 1977; Michael Sonenscher, 'Les sans-culottes de l'an II: repenser le langue du travail dans la France révolutionnaire', Annales. Économies, Sociétés, Civilisations, 40, 1985, 5, pp. $1087-$ 1108; idem, Sans-Culottes: An Eighteenth-Century Emblem in the French Revolution, Princeton, NJ, 2008. For more on riots in London, see Robert B. Shoemaker, 'The London 
century Boston was a city sorely 'tried' by adversity: cycles of recession and considerable rises in unemployment and poverty, the collapse (until 1756) of the shipbuilding industry, explosions of inflation (up to 100 per cent) in 1740-49, smallpox epidemics in 1752 and 1775, the destructive fire of 1760 and the marked rise in taxes after $1768^{65}$ - not to mention the British 'occupation' - the people in Boston decided not to resort to violence and riots; they trusted the procedures of criminal trial to which the British soldiers were brought, although they may have doubted their effectiveness. The case of John Hancock's seized ship stirred up emotions not because a wealthy merchant was caught smuggling wine and lost both his vessel and his cargo, or not even because - in accordance with the existing regulations - one-third of the value of the sold vessel (and wine) went to the informers who had reported the crime (in this case customs officers), but because of the procedure used to adjudicate commercial law cases in America. For the Bostonians a threat to their liberty (and illegal proceeds) lay in the British maritime court (the Admiralty Court), which adjudicated according to the provisions of civil law but without the jury, an institution deeply rooted in the colonists' belief in equality before the law. Arrested on the order of the 'government', Hancock was brought to court in November 1768 (after paying a huge bail of 3,000 pounds), having at his side a lawyer - the young John Adams - who not only rejected the charge, but also questioned the court's jurisdiction in the colonies.

The British, who were observing the trial of their soldiers 'from outside', were convinced that the selection of a twelve-member jury (drawn by lot) by municipal assemblies controlled by their opponents was 'rigged' and made a lenient verdict impossible. General Thomas Gage, commander-in-chief of the British troops in America, informed London that 'they will be condemned. Justly or unjustly, for that no jury will be found in Boston, who will dare, tho' inclined to do so, to give any other Verdict'. ${ }^{66}$ The general expressed an opinion based on a long-standing political polemic in which the colonists' 'constitutional' resistance was seen in London as treason (although this provision of the law was never enacted). After 1765 (the adoption of the Stamp Act) the debate about claims, wrongs, accusations and protests from the other side of the Atlantic was a basic topic in the London press.

\footnotetext{
"Mob" in the Early Eighteenth Century', Journal of British Studies, 26, 1987, 3, pp. 273-304 (with references to earlier literature).

${ }^{65}$ In 1765 Boston, where 6.9 per cent of the population of the province lived, paid 11.2 per cent of all provincial tax, see Menand, 'The Things That Were Caesar's'.

${ }^{66}$ Quoted by John Phillip Reid, 'A Lawyer Acquitted: John Adams and the Boston Massacre Trials', American Journal of Legal History, 18, 1976, 3, p. 193.
} 
John Dickinson's twelve Letters from a Farmer - a catechism of colonial resistance - published by the colonial press and many times as a separate pamphlet, came from the pen of a 'moderate oppositionist', yet for the establishment in the metropolis it was a case of lèse of British majesté and instigation of rebellion. The pamphlet cost two shillings in England. It was promoted by the printer and publisher John Almon, one of the leaders of the English political opposition, favourably disposed to the colonists' arguments. When reviewing the Letters for the English readers, the Critical Review monthly, which sought to take critical note of everything appearing in print in London, did not fail to mention that the author, a certain 'Mr Dickenson', seemed to be a well-educated man, adding, however, that 'without impeaching his veracity we cannot help thinking that he would have proved a much better member of society, had he never learned either to read or write'. The malicious remark of the London gentlemen with regard to the gentleman from Philadelphia - Dickinson was a very wealthy lawyer educated in London (like sixty-five others, children of the rich American elite, in 1722-63) - was just an introduction to scathing criticism. The 'work before us', wrote the reviewers, 'is seditious in its principles, superficial in its execution, and tending to the perdition of a country for which the author is so furious an advocate'. Dickinson was a legalist and advocate of the idea of monarchia mixta; his Letters were full of ancient references and comparisons to Greek and Roman Antiquity, he also drew extensively on the juridical legacy of English constitutionalism, which he supported. His logical and legal constructs indicate the specificity of the 'political thinking' of a large part of the colonial elite, which was willing to be engaged in a sustained constitutional dispute within the framework of common ideas and experiences. The idea of American independence and breaking the bonds of allegiance filled them with disgust and fear. When a toast was raised in a provincial inn (in Roxbury, on 15 August 1768) to the 'Farmer in Pennsylvania', its words were: 'To Spartan, Roman, British Virtue, and Christian Ethics joined!' - a testimony to a unique combination of various traditions and systems of values on the basis of which the colonial identity was formed. ${ }^{67}$

After reading the Letters their London reviewers concluded, however, that the author's 'arguments [...] tend to prove that the North Americans are as independent upon this country [i.e. Britain - P.T.D.] as the Moors,

${ }^{67}$ Quoted by Richard M. Gummere, 'John Dickinson, the Classical Penman of the Revolution', Classical Journal, 52, 1956, 2, p. 83. 
Tartars or Chinese'. A paradox in the meandering dispute between the Anglo-American intellectuals, who were similarly well-educated and used the same categories in their thinking, was that the 'conservative' Dickinson (he refused to sign the Declaration of Independence) was seen in London as a rabble-rouser seeking to overthrow the legal order of the empire, while radicals like Samuel Adams, who as early as in 1743 in his Latin essay at university posed a question about the limits of civil disobedience, were neither listened to, nor, for a long time, noticed on the political horizon. ${ }^{68}$ Facing the Boston court, John Adams, less politically experienced than Dickinson, had, however, similar political competence - Dickinson's Letters were on his reading list (the two men met in 1774) - while references to the European legal practice, and even more so to ancient precedents, were the basis of his reasoning. As James M. Farrell has indicated, Adams deliberately modelled his discourse in the courtroom on Cicero's speeches, which he knew very well (he had been reading the Roman writer since 1750, in the original at that). ${ }^{69} \mathrm{He}$ found his ideas mainly in De Officiis - a treatise on the ideal of public service of a lawyer defending a doomed man (like the British officer Preston), De Inventione - a speech presenting the logic of the course of action of defence counsel in criminal cases, and Pro Milone, in which the Roman senator expounded an argumentation mechanism that took into account the need of self-defence and justification for murder (Adams had privately commented on the speech already in 1765)..$^{70}$ The Bostonians knew not only the way in which the charges were formulated - during the trial of the soldiers of the 29th Regiment the 'aggrieved city' was represented by the attorney

${ }^{68}$ Critical Review, 26, 1768, p. 62. The number of colonial law students in London after Cyril E.A. Bedwell, 'American Middle Templars', AHR, 25, 1920, 4, pp. 680-89; Bernhard Knollenberg, 'John Dickinson vs. John Adams: 1774-1776', Proceedings of the American Philosophical Society, 107, 1963, 2, pp. 138-44.

${ }^{69}$ James M. Farrell, 'Pro Militibus Oratio: John Adams's Imitation of Cicero in the Boston Massacre Trial', Rhetorica: A Journal of the History of Rhetorics, 9, 1991, pp. 233-49. The mulatto Attucks was a seaman, see Lemisch, 'Jack Tar', p. 399; Mitch Kachun, 'From Forgotten Founder to Indispensable Icon: Crispus Attacks, Black Citizenship and Collective Memory, 1770-1865', Journal of the Early Republic, 20, 2009, 2, pp. 249-86.

${ }^{70}$ Cicero's works were part of the educational canon of eighteen-century lawyers. In 1806 Anne-Louis Girodet-Trioson, a pupil of David, painted a portrait of the famous advocate Raymond Sèze, one of the lawyers defending Louis XVI, author of the famous speech of 26 December 1792. In the portrait de Sèze has his hand on a copy of Cicero's Pro Rege Dejotaro, the famous speech defending the unjustly accused king of the Galatians. See George Levitine, 'David's "Sieyès" in the Fogg Museum and Girodet's De Sèze Mediant la Defence du Roi', Burlington Magazine, 95, 1953, 607, pp. 335-37 (illustration). 
Robert Treat Paine - but they were also aware of the accused's right to defence and of the role of lawyers in conducting the proceedings. ${ }^{71}$

The presence of defence counsel was not surprising to them. Lawyers representing - with the judges' tacit consent - the accused (less often the plaintiffs) began to appear in English courtrooms as early as in the 1730s. In Boston - as in other colonies - lawyers were a privileged profession. In 1769 they were granted their own court building, separate from the city hall. Together with the merchant elite lawyers would determine the civic and political dimension of the life of the city. ${ }^{72}$ We can, of course, argue that in France, too - primarily after a period of conflict between the royal court and the parlements - the role of lawyers increased greatly and that their contribution to the formulation of the reform programme, in evidence during the deliberations of the Estates General, determined the direction of political debates. We can also point to similarities - derived from the shared, 'Enlightenment-inspired' educational canon - in the understanding of the role of the law and the justice system, because, as John Adams wrote, the law came "not from parliament, not from common law but from the law of nature', ${ }^{73}$ that is, with regard to the New England tradition, it was firmly rooted in the Protestant biblical rhetoric, very much alive among the descendants of religious exiles. Contrary to the fear and much to the surprise of General Gage, the trial of his soldiers was not 'rigged'. The jurors proved to be favourably disposed towards the accused (after the outbreak of the revolution five of the twelve emigrated).

Adams's action in the courtroom must have surprised both the Boston mob and the British. Adams referred to a foreigner, the Italian Cesare

${ }^{71}$ On the professional emancipation of lawyers, see William J. Bouwsma, 'Lawyers and the Early Modern Culture', AHR, 78, 1973, 2, pp. 303-27; Robert Blair St. George, 'Massacred Language: Courtroom Performance in Eighteenth-Century Boston', in Possible Pasts: Becoming Colonial in Early America, ed. Robert Blair St. George, Ithaca, NY, 2000, pp. 327-56; Stephen Botein, 'The Legal Profession in Colonial North America', in Lawyers in Early Modern Europe and America, ed. Wilfrid Prest, New York, 1981, pp. 129-46; John M. Murrin, 'The Legal Transformation: the Bench and Bar of Eighteenth-Century Massachusetts', in Colonial America. Essays in Politics and Social Development, ed. Stanley N. Katz, John M. Murrin, 3rd edn, New York, 1983, pp. 540-73; John H. Langbein, 'The Criminal Trial before the Lawyers', University of Chicago Law Review, 45, 1978, pp. 263-316. On the 'common nature' of death sentence in England, see, for example, Vic A.C. Gatrell, The Hanging Tree: Execution and the English People, 1770-1868, New York, 1994, p. 7 (35,000 - the number of death sentences).

${ }^{72}$ Martha J. McNamara, "In the Face of the Court...": Law, Commerce, and the Transformation of Public Space in Boston, 1650-1770', Winterthur Portfolio, 36, 2001, 2-3, pp. 125-39.

${ }^{73}$ Quoted by Felix Rackow, 'The Right to Counsel: English and American Precedents', William and Mary Quarterly, 3rd series, 11, 1954, 1, pp.3-27 (quotation from John Adams, p. 14). 
Beccaria, and tried to demonstrate that death sentence, expected by all, was not an adequate compensation. In his opening address, he said: 'I am for the prisoners at the bar, and I shall apologize for it only in the words of the Marquis Beccaria: If I can but be the instrument of preserving one life, his blessing and tears of transport shall be a sufficient consolation to me for the contempt of all mankind'. ${ }^{74}$ Adams - and his colleagues from the defence team, Josiah Quincy and Samuel Blowers - adopted a line of defence that was controversial to the public: the soldiers had acted in necessary self-defence, while the mob had, in fact, been the aggressor. In his closing speech Adams even went as far as to say that it had been the mob that had acted unlawfully - its 'unlawful design' had been the cause of the bloodshed. Thus he broke with the established tradition of describing the actions of the Boston mob - aggressive, but usually not intent on killing, irreverent, but not guided by a killer instinct. The account published in the London press spoke of young people, teenagers, who deliberately confronted and provoked the soldiers, threw snowballs at them, caused a scene, tried to catch muskets and, putting themselves at risk of being shot, caused a cruel reaction, hitherto unknown to the British soldiers. ${ }^{75}$

The fragment of his closing speech in which Adams defined a mob was of special importance:

We have been entertained with a great variety of names to avoid calling the persons who gathered at the custom-house a mob. The plain English is, gentlemen, a motley rabble of saucy boys, Negroes and mulattoes, Irish teagues and outlandish jack tars. And why should we scruple to call such a set of people a mob? I cannot conceive, unless the name is too respectful of them. The sun is not about to stand still or go out, nor the rivers dry up, because there was a mob in Boston on the fifth of March that attacked a party of soldiers. Such things are not new in the world, nor in the British dominions, though they are, comparatively, rarities and novelties in this town. ${ }^{76}$

${ }^{74}$ Quoted by Marcello Maestro, 'A Pioneer for the Abolition of Capital Punishment: Cesare Beccaria', Journal of the History of Ideas, 34, 1973, p. 465. It seems, however, that, for example, the French constitutional law thought (for example Montesquieu's Esprit des Lois (1748, translated into English in 1750, appeared in Boston book stores in 1762)) and the political reflection of the Enlightenment period were not widely known in America, see Ludwikowski, 'The French Declaration', pp. $447 \mathrm{f}$.

${ }^{75}$ London Magazine, 39, 1770, p. 222 (quotation). On the press as a tool of colonial (and government) propaganda, see William B. Warner, 'Communicating Liberty: The Newspapers of the British Empire as a Matrix for the American Revolution', ELH, 72, 2005, 2, pp. 339-61.

${ }^{76}$ Quoted by Reid, 'A Lawyer Acquitted', p. 202. 
In view of political considerations - or common sense - Adams could not go even further and did not formulate it explicitly in the courtroom; he did not say that it was the Boston mob - over one hundred and twenty people, as Richard Archer has suggested - that was guilty of breaking the law and should be punished for it, and that its leader, a certain Crispin Attucks, 'a runaway slave and seaman', described as a 'stout molatto fellow' ${ }^{77}$ - a model for the would-be Boston sans-culottes, perhaps? - had been the ringleader and criminal killed on the spot. Private Warren, who had shot him and had been charged with murder, was not convicted. Adams was directly challenging the reputation of the city and the 'revolution' it had dared to start, but he may have felt the mood in the courtroom (or judged the chances of this 'revolution') and decided not to formulate the final accusation.

As a result of Adams's brilliant and politically aggressive defence the prosecution dropped the charge in March $1769 .{ }^{78}$ Did Adams, in defending the British soldiers, defend the monarchy, its prerogatives and rights in the colonies against which their inhabitants protested? Perhaps he was merely a legalist concentrating on an individual case of violence, believing, like most of his American compatriots, that his opponent was the unjust British parliament? The thesis that in Boston monarchy was tried by proxy is at best risky, although all the more attractive, as it enables us - briefly to draw analogies with the 'trial of the century', during which the body politic judged Louis XVI. A trial of a king, wrote Michael Walzer, changes the nature of the monarchy, ${ }^{79}$ and execution does not allow it to survive. Walzer was interested above all in the political games surrounding the trial: the reluctance of the Jacobins to try Louis in the first place, because Louis was neither a ruler, nor a citizen, but only an 'alien' who had to be killed, because such was a logical consequence of deposition, and the obsessive faith of the Girondins in the principles of the law whereby he precisely as a citizen - had to be brought to court. ${ }^{80}$ One of the differences

${ }^{77}$ His physical strength and size were commented upon by John Adams, see Kachun, 'From Forgotten Founder to Indispensable Icon', p. 251.

${ }^{78}$ The fate of Private William Warren after Zobel, The Boston Massacre, pp. 182-83, 244, 294. See Archer, As If an Enemy's Country, pp. 198-99; Lovejoy, 'Rights Imply Equality', pp. 479-81; cf. John M. Beattie, 'Scales of Justice: Defense Counsel and the English Criminal Trial in the Eighteenth and Nineteenth Centuries', Law and History Review, 9, 1991, 2, pp. 221-67.

${ }^{79}$ Regicide and Revolution: Speeches at the Trial of Louis XVI, ed. Michael Walzer, transl. Marian Rothstein, New York, 1974.

${ }^{80}$ When reviewing Walzer's book, Robert R. Palmer (in Political Theory, 3, 1975, pp. 103-06) noted that the Convention had no problem with finding the accused guilty, but was in trouble when trying to send him to the guillotine by a majority 
in the perception of the enforcement of justice, regardless of whether we term the process 'popular' or not, was the fact that everyone, including the British soldiers' superiors, agreed to their trial in a civil court.

The revolutions in Boston and Paris enacted their scenarios of 'theatres of justice' in a fundamentally different manner. As Laura Mason has written, in France the revolution led to an explosion of the practice of public speaking, lively means of communication, and gave the courtrooms open to the public - a hitherto unknown dimension of social openness. ${ }^{81}$ With time this led to absurdities of transparency - the image is brought to mind by the Parisian tricoteuses knitting in the courtroom (albeit without the right to speak), when the fate of Louis XVI was being decided. After 1791 the evolution of 'popular justice' turned into a caricature of the trial, deliberately correcting, however, the old procedure. As Elizabeth Samet has reminded us, the revolution in France - in the opinion of its critics like Edmund Burke - became a paradigm of social and moral tragedy, a theatre of national disaster. ${ }^{82}$ In Boston the use of the living word in the courtroom had had a longer history. It was rooted in the British trial tradition and, more broadly, in the concept of civil society, formulated - in opposition to France's experiences - by Burke in his Reflections on the Revolution in France in 1790. As Neil L. York has remarked, 'Americans left the empire with their respect for English law undiminished'. ${ }^{83}$ In Paris the sans-culottes - both the 'genuine' and the 'invented' ones were a response to the radical break with the past; in Boston there was no need to stimulate them and 'invent' a separate identity for them, because the past was an inalienable element of political protest and social order which required a major correction but not denial.

(Translated by Anna Kijak)

vote. The problem of the Girondins (178 deputies) lay in getting a majority - winning the votes of 250 deputies from the 'centre'. They could not count on the over 300 'Mountain Men'. The trial is discussed by David P. Jordan, The King's Trial: the French Revolution vs. Louis XVI, Berkeley and Los Angeles, CA, 1979.

${ }^{81}$ Laura Mason, "The "Bosom of Proof": Criminal Justice and the Renewal of Oral Culture during the French Revolution', JMH, 76, 2004, 1, pp. 29-61; Elizabeth D. Samet, 'Spectacular History and the Politics of Theater: Sympathetic Arts in the Shadow of the Bastille', PMLA, 118, 2003, 3, pp. 1305-19; Susan Maslan, 'Resisting Representations: Theater and Democracy in Revolutionary France', Representations, 52, 1995, pp. 27-51.

${ }^{82}$ Samet, 'Spectacular History', pp. 1313 ff. Cf. Siraj Ahmed, 'The Theater of the Civilized Self: Edmund Burke and the East India Trials', Representations, 78, 2002, pp. 28-55.

${ }^{83}$ York, 'Imperial Impotence', p. 701. 


\section{Summary}

The article applies a comparative perspective to assess the onset of the two 'successful' eighteen-century revolutions - the American and the French. It compares the strategies of initiating a politically meaningful change and the differences in managing the revolutionary process. Based on press reports, pamphlets and memoires the Boston events of March 1770 are viewed against those of Paris in July 1789. In both cases 'the people' faced the soldiers but the subsequent actions of the insurgents showed a marked difference in understanding the sense of justice and ways of promoting revolutionary discourse. Boston patriots relied on the English-based system of common law, were ready to condemn their own radicals and did not wish plebeian justice to prevail. They hoped for a perestroika, not for a revolution. The French - finding no culprits to condemn, and having as of yet no legal institutions of their own to use - were willing to disregard the legal continuity of the state and search for more radical solutions.

\section{Bibliography}

Alder, Ken, 'Stepson of the Enlightenment: the Duc du Châtelet, the Colonel who

"Caused” the French Revolution', Eighteenth-Century Studies 12,1998, 1, pp.1-18. Andrews, Richard M., Law, Magistracy, and Crime in Old Regime Paris, 1735-1789, Cambridge: Cambridge University Press, 1994, vol. 1: The System of Criminal Justice. Applewhite, Harriet B., 'Political Legitimacy in Revolutionary France, 17881791', Journal of Interdisciplinary History, 9, 1978, 2, pp. 245-73.

Archer, Richard, As If an Enemy's Country: The British Occupation of Boston and the Origins of Revolution, New York: Oxford University Press, 2010.

Bailyn, Bernard, The Ideological Origins of the American Revolution, Cambridge, MA: Belknap Press of Harvard University Press, 1967.

Birn, Raymond, 'Reinventing le Peuple of 1789', History Teacher 23, 1990, 4, pp. 363-73. Blair St. George, Robert, Massacred Language: Courtroom Performance in Eighteenth-Century Boston, in Possible Pasts: Becoming Colonial in Early America, ed. Robert Blair St. George, Ithaca, NY: Cornell Univeristy Press, 2000, pp.327-56.

Bryant, Lawrence M., 'Royal Ceremony and the Revolutionary Strategies of the Third Estate', Eighteenth-Century Studies, 22, 1989, 3, pp. 413-50.

Bukovansky, Mlada, Legitimacy and Power Politics: The American and French Revolutions in International Political Culture, Princeton, NJ: Princeton University Press, 2002.

Caron, Pierre, 'La tentative de contre-révolution de juin-juillet 1789', Revue d'histoire moderne et contemporaine, 8, 1906-1907, 1 and 9, pp.3-34,649-78.

Chagniot, Jean, 'Le Guet et la Garde de Paris à la fin de l'Ancien Régime', Revue d'histoire moderne et contemporaine, 20,1973, 1, pp. 58-71. 
Christofferson, Michael S., 'An Antitotalitarian History of the French Revolution: François Furet's "Penser la Révolution française" in the Intellectual Politics of the Late 1970's', French Historical Studies, 22, 1999, 4, pp.557-611.

Cogliano, Francis D., 'Deliverance from Luxury: Pope' Day, Conflict and Consensus in Colonial Boston, 1745-1765', Studies in Popular Culture, 15, 1993, 2, pp. 15-28.

Fitzsimmons, Michael P., The Night the Old Regime Ended: August 4, 1789 and the French Revolution, University Park, PA: Pennsylvania State University Press, 2003.

Garrioch, David, Neighbourhood and Community in Paris, 1740-1790, Cambridge: Cambridge University Press, 1986.

Hesse, Carla, 'La preuve par lettre. Pratiques juridiques au tribunal révolutionnaire de Paris (1793-1794)', Annales. Histoire, Sciences Sociales, 51, 1996, 3, pp. 629-42.

Howell, Peter, 'Burke, Paine and the Newspapers: An Archaeology of Political Knowledge, 1789-93', Studies in Romanticism, 43, 2003, 4, pp. 357-98.

Lemisch, Jesse, 'Jack Tar in the Streets: Merchant Seamen in the Politics of Revolutionary America', William and Mary Quarterly, 3rd series, 25, 1968, 3, pp. 371-407.

Levi, Giovanni, 'On Microhistory', in New Perspectives on Historical Writing, ed. Peter Burke, Cambridge: Polity Press, 1991, pp. 93-113.

Luckett, Thomas A., 'Hunting for Spies and Whores: A Parisian Riot on the Eve of the French Revolution', Past \& Present, 156, 1997, pp. 116-43.

Ludwikowski, Rett R., 'The French Declaration of the Rights of Man and the American Constitutional Development', American Journal of Comparative Law, 38, 1990, pp. 445-62.

Lüsebrink, Hans-Jürgen, and Rolf Reichardt, 'La "Bastille” dans l'imaginaire social de la France à la fin du XVIII siècle (1774-1799)', Revue d'histore moderne et contemporaine, 30, 1983, 2, pp. 196-234.

Mason, Laura, 'The "Bosom of Proof": Criminal Justice and the Renewal of Oral Culture during the French Revolution", Journal of Modern History, 76, 2004, 1, pp. 29-61.

McNamara, Martha J., “"In the Face of the Court...”: Law, Commerce, and the Transformation of Public Space in Boston, 1650-1770', Winterthur Portfolio, 36, 2001, 2-3, pp. 125-39.

Maier, Pauline, From Resistance to Revolution: Colonial Radicals and the Development of American Opposition to Britain, 1765-1776, New York: Alfred A. Knopf, 1972.

Maier, Pauline, 'Popular Uprising and Civil Authority in Eighteenth-Century America', William and Mary Quarterly, 3rd series, 27, 1970, 1, pp. 3-35.

Maza, Sarah, 'Politics, Culture and the Origins of the French Revolution', Journal of Modern History, 61, 1989, 4, pp. 704-23.

Ozouf, Mona, La Fête révolutionnaire, 1789-1799, Paris: Gallimard, 1976.

Popkin, Jeremy, 'Not Over After All: The French Revolution's Third Century', Journal of Modern History, 74, 2002, 4, pp. 801-21.

Reid, John Phillip, In a Rebellious Spirit: The Arguments of Fact, the Liberty Riot, and the Coming of the American Revolution, University Park, PA: Pennsylvania State University Press, 1979. 
Samuelson, Richard A., 'The Constitutional Sanity of James Otis: Resistance Leader and Loyal Subject', Review of Politics 61, 1999, 3, pp. 493-523.

Schama, Simon, Citizens: A Chronicle of the French Revolution, New York: Alfred A. Knopf, 1989.

Scott, Samuel F., 'Problems of Law and Order during 1790, the "peaceful" Year of the French Revolution', American Historical Review, 80, 1975, 4, pp. 859-80.

Sewell, William H. Jr., 'Historical Events as Transformations of Structures: Inventing Revolution at the Bastille', Theory and Society, 25, 1996, pp. 841-81.

Shapiro, Barry M., 'Revolutionary Justice in 1789-1790: The Comité des Recherches, the Châtelet, and the Fayettist Coalition', French Historical Studies, 17, 1992, 3, pp. 656-69.

Sonenscher. Michael, Sans-Culottes: An Eighteenth-Century Emblem of the French Revolution, Princeton, NJ, 2008.

Spagnoli, Paul G., 'The Revolution Begins: Lambesc's Charge, 12 July 1789', French Historical Studies, 17, 1991, 2, pp. 466-97.

Tackett, Timothy, Becoming a Revolutionary: The Deputies of the French National Assembly and the Emergence of a Revolutionary Culture, 1789-1790, Princeton, NJ: Princeton University Press, 1996.

Tackett, Timothy, When the King took Flight, Cambridge, MA: Harvard University Press, 2003.

Tyler, John W., Smugglers and Patriots: Boston Merchants and the Advent of the American Revolution, Boston, MA: Northeastern University Press, 1986.

York, Neil L., 'Rival Truths, Political Accommodation, and the Boston "Massacre"', Massachusetts Historical Review, 11, 2009, pp. 57-95.

Zobel, Hillier B., The Boston Massacre, New York: W. W. Norton, 1970.

B iogr a phy: Paweł T. Dobrowolski, PhD. - professor of international studies in the Collegium Civitas, Warsaw, head of Sociology, Political and International Studies Department, PhD (1983) Institute of History, Polish Academy of Sciences, habilitationshrift (1998), former diplomat (ambassador to Canada 2000, Cyprus 2009), field of interest: eighteenth-century Britain. Contact: pawdob@hotmail.com. 